\title{
Antibiotics as immunomodulators: a potential pharmacologic approach for ARDS treatment
}

\author{
Andrea Sauer (D), Konrad Peukert (1), Christian Putensen and Christian Bode (1) \\ Dept of Anesthesiology and Intensive Care Medicine, University Hospital Bonn, Bonn, Germany.
}

Corresponding author: Christian Bode (christian.bode@ukbonn.de)

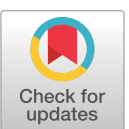

This version is distributed under the terms of the Creative Commons Attribution NonCommercial Licence 4.0. For commercial reproduction rights and permissions contact permissions@ersnet.org

Received: 11 April 2021 Accepted: 2 July 2021

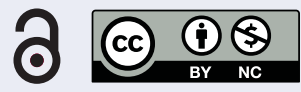

Shareable abstract (@ERSpublications)

ARDS carries an unacceptably high mortality. No effective pharmacological therapy has been identified underlining the need for new therapeutic agents. Antibiotics are promising immunomodulators that may reverse the uncontrolled immune response in ARDS. https://bit.ly/ $3 \mathrm{r} 9 \mathrm{ApH} 3$

Cite this article as: Sauer A, Peukert K, Putensen C, et al. Antibiotics as immunomodulators: a potential pharmacologic approach for ARDS treatment. Eur Respir Rev 2021; 30: 210093 [DOI: 10.1183/ 16000617.0093-2021].

\section{Abstract}

First described in the mid-1960s, acute respiratory distress syndrome (ARDS) is a life-threatening form of respiratory failure with an overall mortality rate of approximately $40 \%$. Despite significant advances in the understanding and treatment of ARDS, no substantive pharmacologic therapy has proven to be beneficial, and current management continues to be primarily supportive. Beyond their antibacterial activity, several antibiotics such as macrolides and tetracyclines exert pleiotropic immunomodulatory effects that might be able to rectify the dysregulated inflammatory response present in patients with ARDS. This review aims to provide an overview of preclinical and clinical studies that describe the immunomodulatory effects of antibiotics in ARDS. Moreover, the underlying mechanisms of their immunomodulatory properties will be discussed. Further studies are necessary to investigate their full therapeutic potential and to identify ARDS phenotypes which are most likely to benefit from their immunomodulatory effects.

\section{Introduction}

Since Ashbaugh and colleagues first described acute respiratory distress syndrome (ARDS) in 1967, it has remained a life-threatening condition with high mortality rates and limited treatment options [1, 2]. In a recent international study, ARDS accounted for $10 \%$ of total intensive care unit admissions and $24 \%$ of patients with mechanical ventilation. Hospital mortality ranged between 35\% and 46\% [3]. Survivors may battle with long-term cognitive and physical impairment such as depression, post-traumatic stress disorder, muscle weakness and pulmonary fibrosis long after their recovery from ARDS [4]. Treating the underlying cause and supportive care continue to be the mainstay of therapy [2]. Despite advances in its supportive treatment such as lung protective ventilation, prone positioning or a restrictive fluid regimen, pharmacologic therapies including statins, $\beta 2$-agonists and nitric oxide (NO) have failed to show a survival benefit [5].

Particularly relevant in view of the ongoing coronavirus disease 2019 (COVID-19) pandemic, new therapeutic approaches for ARDS are urgently needed. Certain antibiotic classes including macrolides, tetracyclines, fluoroquinolones and oxazolidinones are reported to be generally safe with rare major side effects and exhibit immunomodulatory properties beyond their antibacterial effects [6]. These immunomodulatory effects have been proven to be beneficial in the treatment of chronic inflammatory respiratory diseases including asthma, cystic fibrosis, diffuse panbroncheolitis and bronchiectasis [7]. There is mounting evidence that it could also be favourable in acute inflammatory processes such as pneumonia and ARDS [8, 9].

We performed a comprehensive literature search in PubMed for all relevant studies published between 1 January 1995 and 31 May 2021, with English-language restriction. In addition, pivotal studies were 
identified by looking at reference lists of original and review articles. The main keywords included the main antibiotic classes and its members combined with the following keywords: "immunomodulation", "immunomodulatory”, “immune system”, “immune response”, “inflammatory”, “inflammation”, “cytokine”, “neutrophil”, “pneumonia”, “pulmonary infection”, “influenza”, “acute lung injury” and "ARDS". The relevant articles were initially screened by reading the abstract. If this was not sufficient to determine eligibility, the full text was read, and non-related articles were removed. All of the included references were classified according to cause of ARDS/acute lung injury and study design (in vitro studies, in vivo animal studies and clinical studies in humans). In the present review, we summarise the immunomodulatory effects of antibiotics in ARDS and provide promising antibiotic candidates for future testing in clinical trials.

\section{Pathogenesis of ARDS: dysregulated inflammation is a hallmark of ARDS}

\section{Toll-like receptor signalling and involvement of the NLRP3 inflammasome in ARDS}

ARDS is a heterogeneous syndrome mostly caused by viral and bacterial pneumonia, aspiration of gastric contents, non-pulmonary sepsis and major trauma. Dysregulated innate immunity plays a profound role in the pathophysiology of ARDS. The release of inflammatory mediators, innate immune cell infiltration and other pathways of injury cause the disruption of the blood-air barrier, which leads to influx of protein-rich pulmonary oedema fluid and lung injury (figure 1) [5, 10]. Key elements of the innate immune response

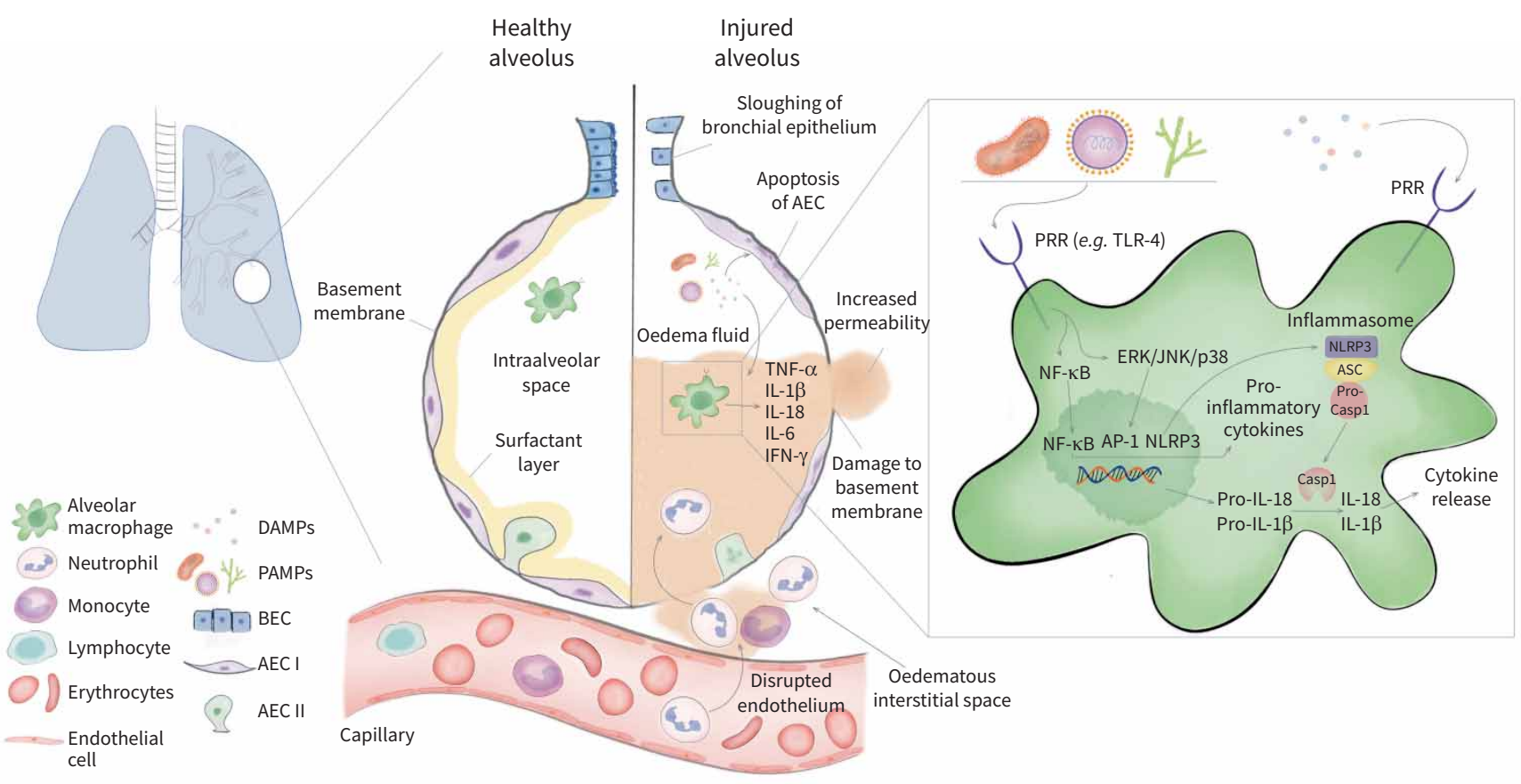

FIGURE 1 Immuno-pathogenesis of acute respiratory distress syndrome (ARDS). In the healthy alveolus the epithelium consists of a continuous monolayer of type I and type II alveolar epithelial cells covered by a surfactant layer. Resident alveolar macrophages populate the intraalveolar space and orchestrate the inflammatory response induced by direct (pulmonary) or indirect (extrapulmonary) insults. Conserved microbial motifs so called pathogen-associated molecular patterns (PAMPs) or cell injury-associated endogenous molecules referred to as damage-associated molecular patterns (DAMPs) are recognised by pattern recognition receptors (PRRs), such as Toll-like receptors (TLRs), which are located on macrophages and various other immune cells. The subsequent activation of downstream signalling pathways including NF- $\mathrm{KB}$ and mitogen-activated protein kinases (extracellular signal-regulated kinase (ERK), C-Jun N-terminal kinase (JNK), p38) induces the upregulation of proinflammatory cytokines and chemokines which stimulate the transepithelial migration of neutrophils and monocytes. Excess inflammation causes alveolar cell and capillary endothelial injury resulting in the disruption of the blood-air barrier that causes the accumulation of protein-rich oedema fluid within the lungs. A key driver of the inflammatory response is the NLRP3 inflammasome which is composed of a sensor NOD-, LRRand pyrin domain-containing protein 3 (NLRP3), an adaptor apoptosis-associated speck-like protein containing caspase-recruitment domain-containing protein (ASC) and an effector (caspase-1) and leads to the release of proinflammatory cytokines interleukin (IL)-1 $\beta$ and IL-18. The activation of NLRP3 requires two steps. Signal 1 is mediated by PRRs and NF-KB-regulated transcription of pro-caspase-1, pro-IL-1 $\beta$ and pro-IL-18. The activation signal (signal 2) is provided by a wide range of stimuli including ATP, viral RNA and pore-forming toxins, which lead to the assembly of the NLRP3 inflammasome-caspase-1 complex. This complex proteolytically cleaves pro-IL-1 $\beta$ and pro-IL-18 into their active forms and causes a highly inflammatory form of programmed cell death called pyroptosis. AEC I: type I alveolar epithelial cell; AEC II: type II alveolar epithelial cell; BEC: bronchial epithelial cell; CASP1: caspase-1; IFN: interferon; MAPKs: mitogen activated protein kinases. 
are pattern recognition receptors (PRRs) including Toll-like receptors (TLRs) that sense the presence of highly conserved microbial motifs called pathogen-associated molecular patterns (PAMPs) and cell injury-associated endogenous molecules referred to as damage-associated molecular patterns [11]. Following ligand binding, PRRs (e.g., TLR-4) activate downstream signalling pathways, such as NF-kb and mitogen-activated protein kinase (MAPK). This leads to the transcription of genes encoding proinflammatory cytokines and chemokines such as interleukin (IL)-1 $\beta$ and IL-18 [11-14]. The expression of IL-1 $\beta$ and IL-18 is controlled by inflammasomes, which are multiprotein complexes consisting of a sensor, the adapter protein apoptosis-associated speck-like protein containing caspase-recruitment domain-containing protein (ASC) and caspase-1 [15]. Sensors include the nucleotide-binding oligomerisation domain-like receptor family, pyrin domain containing protein-3 (NLRP3). Inflammasome activation is tightly regulated and requires two steps: priming and activation. The priming step (signal 1) is mediated by PAMPs binding to PRRs (e.g. lipopolysaccharide (LPS) to TLR-4). As a result, NF-kb activation leads to a subsequent expression of pro-caspase-1, pro-IL-1 $\beta$ and pro-IL-18. The activation step (signal 2) is caused by various stimuli including ATP, viral RNA and pore forming toxins. Once the sensor such as NLRP3 becomes activated, ASC dimers assemble to form the pyroptosome resulting in the activation of pro-caspase 1 . Active caspase- 1 proteolytically cleaves pro-IL-1 $\beta$ and pro-IL-18 into active cytokines. Furthermore, active caspase-1 drives pyroptosis, a form of highly inflammatory programmed cell death [15, 16] (figure 1). IL-1 $\beta$, IL-18 and caspase-1 play important roles in favouring the development of ARDS and are associated with poor outcomes [9, 12, 17].

\section{Divergent role of alveolar macrophages in ARDS}

Key orchestrators of the innate immune cell mediated onset of ARDS are mainly alveolar macrophages $[18,19]$. During pulmonary inflammation, alveolar macrophages exist in a balance of proinflammatory (M1) macrophages and anti-inflammatory (M2) macrophages. In the acute exudative phase, resident alveolar macrophages and recruited monocytes skew toward an M1 activation state by T-helper cell (Th) 1 cytokines interferon (IFN)- $\gamma$ and LPS. Transcription factors that mediate an M1 activated phenotype include NF- $\kappa b$, signal transducer and activator of transcription 1 (STAT1) [18]. During the later stages of ARDS, macrophages undergo a phenotypic switch from M1 to M2, which is induced by Th2 cytokines such as IL-4, IL-10 and transcription factors including STAT3 [18].

\section{Involvement of neutrophil influx in ARDS}

Upon entering the alveolar airspace neutrophils release toxic mediators including reactive oxygen species (ROS), neutrophil elastase (NE) and matrix metalloproteinases (MMPs), which have all been associated with the propagation of ARDS [20, 21, 22]. Neutrophil apoptosis and subsequent efferocytosis, the clearance of neutrophils by macrophages, is a critical step in the resolution of inflammation [23]. In ARDS patients, neutrophil apoptosis is delayed and its extent correlates with disease severity [24-26].

\section{Immunomodulatory effects of antibiotics in ARDS}

\section{Macrolides}

The most frequently used macrolides are characterised by a 14-, 15- or 16-membered macrolactone ring with a broad spectrum of bacterial activity against Gram-positive and Gram-negative pathogens. They block the initiation of protein synthesis by reversibly binding to the 50-s-subunit of the bacterial ribosome [27].

\section{Mechanisms of action}

Macrolides exert a plethora of immunomodulatory effects that have been well described for chronic inflammatory lung diseases and influence all stages of ARDS [28]. The mechanisms underlying these effects will be discussed in detail below.

Effects on TLR signalling and NLRP3 inflammasome activation

Macrolides impair the activation of the NLRP3 inflammasome [29, 30] (figure 2). Azithromycin inhibited the LPS-induced expression of IL-1 $\beta$ in vitro and in vivo and prevented the induction of caspase- 4 while not suppressing NF-кb [29]. Through the suppression of inflammasome-dependent IL-1 $\beta$ and IL-18 release, azithromycin alleviated lung injury in a murine model of Pseudomonas aeruginosa infection [30]. Furthermore, azithromycin reduced LPS-induced pulmonary neutrophilia by the reduction of IL-1 $\beta$ expression in murine alveolar macrophages. This inhibition of IL-1 $\beta$ gene expression by azithromycin was attributed to blocking of transcription factor activator protein (AP)-1 while the NF-kb and MAPK/ extracellular signal-regulated kinase (ERK) pathways were not affected and inflammasome assembly not investigated [31]. However, current research suggests that azithromycin does in fact block the activation of

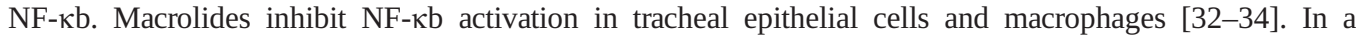
murine LPS-induced lung injury model, azithromycin significantly dampened NF- $\mathrm{kb}$ activation in a 


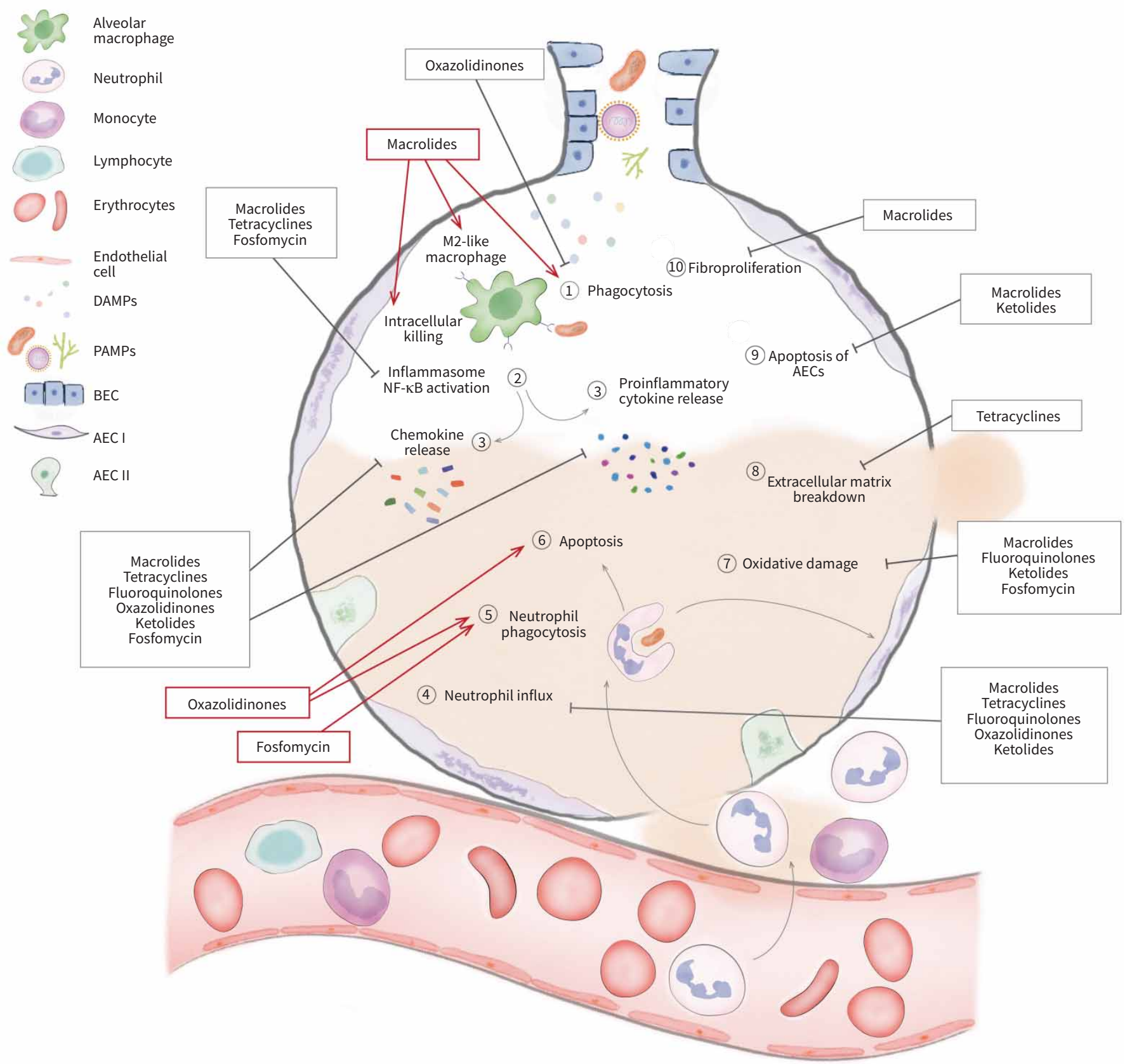

FIGURE 2 Immunomodulatory effects of antibiotics in acute respiratory distress syndrome (ARDS). (1) After pathogen invasion, macrolides enhance macrophage phagocytotic activity while oxazolidinones suppress phagocytosis. Macrolides promote the polarisation of proinflammatory M1 to anti-inflammatory M2 macrophages. (2) By sensing pathogen-associated molecular patterns (PAMPs) and damage-associated molecular patterns (DAMPs), Toll-like receptors (TLRs) become activated thereby triggering the activation of NF- $\mathrm{KB}$ which mediates the induction of proinflammatory cytokines and chemokines and the upregulation of the nucleotide-binding oligomerisation domain-like receptor family, pyrin domain containing protein-3 (NLRP3) inflammasome. Macrolides, tetracyclines and fosfomycin inhibit the activation of NF-KB and the NLRP3 inflammasome. (3) Macrolides, fluoroquinolones, ketolides, oxazolidinones, fosfomycin and tetracyclines inhibit the release of proinflammatory cytokines and chemokines causing impaired chemotaxis of immune cells (4) such as neutrophils and monocytes into the lungs. (5) Oxazolidinones and fosfomycin restore the phagocytotic capabilities of neutrophils. (6) Furthermore, they increase neutrophil apoptosis which is delayed in ARDS patients. (7) The oxidative damage caused by the generation of reactive oxygen species and nitric oxide (NO) metabolites by immune cells is decreased by macrolides, ketolides and fluoroquinolones. Fosfomycin also exhibits antioxidative properties. (8) Tetracyclines, as potent matrix metalloproteinase inhibitors, reduce extracellular matrix breakdown. (9) Macrolides and ketolides decrease apoptosis of alveolar epithelial cells while macrolides also prevent fibroproliferation. (10) The overall immunomodulatory effect of antibiotics in ARDS focuses on mitigating tissue injury by decreasing the intensity of an uncontrolled inflammatory response and enabling tissue repair. $\perp$ : Inhibition; $\rightarrow$ : stimulation; AEC I: type I alveolar epithelial cell; AEC II: type II alveolar epithelial cell; BEC: bronchial epithelial cell. 
concentration-dependent manner [35]. Clarithromycin also decreased NF-kb activation in a murine ventilator-induced lung injury (VILI) model [36].

\section{Effects on cytokines and chemokines}

Several preclinical studies have shown that macrolides inhibit the release of proinflammatory cytokines in vitro and in vivo, thereby dampening the innate immune response [28, 37]. Macrolides significantly decrease levels of proinflammatory cytokines (e.g. IL-1 $\beta$, IL-5, IL-6, IL-17, IL-18, tumour necrosis factor- $\alpha(\mathrm{TNF}-\alpha)$ ) and chemokines (e.g. C-X-C motif chemokine ligand (CXCL) 8, CXCL9) in the lungs, thereby reducing lung injury [30, 35, 38-43].

Though macrolides appear to inhibit proinflammatory cytokines, they exert nebulous effects on anti-inflammatory cytokines. In murine models of viral or bacterial pulmonary infection, macrolides increased or did not influence IL-10 levels in serum, lung tissue and bronchooalveolar lavage fluid (BALF) [38, 39]. Increased IL-10 levels were likely linked to a clarithromycin-mediated augmentation of an immunosuppressive population of myeloid-derived suppressor cells (MDSCs) which improved survival in a murine LPS-induced lethal shock and post-influenza clarithromycin-resistant pneumococcal lung injury model [39].

Effects on chemotaxis of immune cells

Macrolides are known to block the release of chemotactic factors thereby suppressing the recruitment of immune cells such as neutrophils, fibroblasts and macrophages [28]. The administration of macrolides resulted in reduced neutrophil infiltration of the lung and consequently improved lung injury in murine models of bacterial infection, virus-, bleomycin- and VILI [30, 36, 43-48]. Diminished neutrophil counts were associated with a decreased number of apoptotic epithelial cells [45]. This might be explained by the following findings. Azithromycin inhibited the secretion of chemoattractants granulocyte-macrophage colony-stimulating factor and IL-8/CXCL8 by LPS-treated primary bronchial epithelial cells [49]. Macrolides prevented chemotaxis by downregulating IL-6, CXCL1, 2 and 8, CC chemokine receptor (CCL) 2 and 3, and the cell adhesion molecule E-selectin in vitro and in vivo [35, 36, 43, 45-48, 50, 51]. The inhibition of neutrophil migration was in part attributed to the blockage of the MAPK/ERK signalling pathway [46].

\section{Effects on phagocytosis and macrophage polarisation}

In ARDS patients the phagocytotic capacity of macrophages is impaired [52]. Macrolides enhance the phagocytotic capacity of alveolar macrophages [53, 54]. In patients with COPD, which is associated with defective phagocytosis, azithromycin restored the phagocytotic ability of monocyte-derived and alveolar macrophages [55]. KumAR et al. [44] demonstrated that clarithromycin significantly increased phagocytotic uptake and intracellular killing in a murine model of Klebsiella pneumoniae infection and contributed to an amelioration of lung injury.

Moreover, macrolides have been reported to shift macrophages to an alternatively activated anti-inflammatory M2-like phenotype marked by the expression of arginase 1, the mannose receptor and a downregulation of proinflammatory cytokines [33, 38, 56] (figure 2). This phenotypic switch macrophages undergo is likely caused by the inhibition of NF- $\mathrm{kb}$ and STAT1 [33]. Furthermore, macrolides dampen the hyperinflammatory response in ARDS by expanding immunoregulatory monocytic and granulocytic MDSCs through increased phosphorylation of STAT3 [38, 39].

Animal studies

Effects on the development of pulmonary fibrosis in ARDS

In a limited number of patients ARDS can progress into a final fibrotic stage induced by a persistent inflammatory trigger. There is growing evidence that fibroproliferation is present early in the pathogenesis of ARDS. Since it seems to occur in parallel to the exudative and proliferative phase new pharmacologic agents need to exhibit anti-inflammatory and anti-fibrotic properties [57, 58]. In a murine radiation-induced lung injury model Tang et al. have shown that azithromycin down-regulated the concentration of proinflammatory cytokines IL-1 $\beta$, IL-6 and TNF- $\alpha$. In addition, azithromycin attenuated the irradiation-induced expression of fibrotic markers including the profibrotic cytokine transforming growth factor- $\beta 1$ (TGF- $\beta 1$ ), $\alpha$-smooth muscle actin and $\alpha-1$ type I collagen (COL1A1) [40]. Azithromycin also reduced bleomycin-induced lung fibrosis and restrictive lung pattern in a murine model [59]. WuYTs et al. [59] reported that collagen deposition and fibroblast proliferation were markedly reduced after administration of azithromycin, which might be explained by the fact that azithromycin has been shown to accumulate well in human fibroblasts [60]. A non-antibiotic macrolide, the erythromycin derivative EM703 reduced type 1 collagen production by downregulating the transcription of COL1A1 in human fibroblasts [61]. 
By modulating TGF- $\beta 1$ signalling in lung fibroblasts, EM703 was able to reduce collagen production in a murine bleomycin-induced pulmonary fibrosis model, suggesting a potential role in the prevention and treatment of post-ARDS fibrosis [62] (figure 2).

Effects on virus-induced ARDS

Contradictory data have been reported on the adjunctive use of macrolides in murine virus-induced lung injury. The use of erythromycin in a murine influenza-induced lung injury model led to lower numbers of immune cells in BALF and the secretion of IFN- $\gamma$ was inhibited, thereby increasing survival. Mice also showed a significantly lower inducible NO synthase-induction potential [63]. In a murine study investigating the prophylactic application of azithromycin in respiratory syncytial virus (RSV)-induced lung injury levels of IL-5, IL-6 and IFN- $\gamma$ were significantly reduced. Moreover, mice displayed less weight loss, less airway inflammation and lower mortality [41]. In contrast, a combination therapy of oseltamivir-azithromycin compared to oseltamivir monotherapy did not provide additional benefits in mice infected with influenza [64]. However, this study had several limitations. First of all, the study designs differed significantly in terms of dosing and treatment duration. FAGE et al. [64] only applied a single dose of azithromycin on day 3 post-inoculation. Viral titres were reduced but the combined therapy of azithromycin and oseltamivir did not improve survival probably due to the fact that severe lung injury had already occurred on day 3.

\section{Human data}

Recent studies have shown that low-dose macrolide therapy was linked to a survival benefit in ARDS patients [65-68]. Macrolide therapy was associated with reduction in mortality of $9-13 \%$ and shorter time to successful discontinuation of mechanical ventilation [65, 66, 69]. In a multicentre study with 200 patients who suffered from septic shock due to ventilator-associated pneumonia (VAP), the use of clarithromycin led to significantly lower TNF- $\alpha$ and higher IL-6 levels than among the control group. Moreover, clarithromycin treatment restored the balance between pro-inflammatory and anti-inflammatory cytokines as measured by the TNF- $\alpha / \mathrm{IL}-10$ ratio [8]. A prospective study on 52 patients with non-responding community-acquired pneumonia showed that macrolide treatment lowered IL- 6 and TNF- $\alpha$ in BALF and IL-6, IL-8 and IL-10 in plasma. Patients had a reduced hospital length of stay and reached clinical stability faster [70]. Adjunctive macrolide treatment also decreased pro-inflammatory cytokine release including IL-6, IL-8, IL-17, IL-18, CXCL9 and soluble TNF receptor in 50 patients with severe influenza pneumonia which was associated with a trend toward faster recovery [42].

In a randomised phase 2 clinical trial that included 48 children with RSV-induced respiratory failure, high-dose azithromycin treatment reduced MMP-9 levels, TNF- $\alpha$, IL-1 $\beta$ and IL-10. Reduced numbers of ventilator support and oxygen days as well as a shorter hospital stay were observed in the high-dose azithromycin group. High doses of azithromycin were considered safe [71].

In contrast, a recent retrospective analysis involving 7182 patients with respiratory failure including ARDS of whom 1295 patients received macrolide treatment found no difference in mortality, mechanical ventilation duration, or incidence of secondary infection. The inconsistency with previous results may be explained by differences in timing and frequency of dosing [72].

\section{Ketolides}

The ketolide antibiotic telithromycin is derived from a 14-membered macrolide by substituting the L-cladinose moiety for a ketogroup. As a macrolide derivative, it also blocks bacterial protein synthesis and exhibits similar immunomodulatory effects both in vitro and in vivo [73, 74]. Telithromycin suppressed the release of the chemokine CXCL2/macrophage inflammatory protein (MIP)-2 $\alpha$ by pulmonary epithelial cells treated with supernatant of LPS-stimulated macrophages. In addition, the activation of NF-kb was inhibited and there was an increase in apoptosis in both cell lines (figure 2). In a mouse model of LPS-induced lung injury, telithromycin decreased the number of neutrophils, protein, nitrite, CXCL2 and TNF- $\alpha$ levels in BALF [75].

\section{Tetracyclines}

Tetracyclines belong to a family of broad-spectrum antibiotics that are indicated for community-acquired pneumonia, Lyme disease, cholera, sexually transmitted diseases, and others. They inhibit protein synthesis by reversibly binding to the 30s ribosomal subunit and prevent the amino acyl-tRNA from binding to the A site of the ribosome [76]. In addition to their antibacterial properties, they also display pleiotropic anti-inflammatory properties. 
Mechanism of action

Tetracyclines reduce inflammasome-mediated lung injury by inhibiting caspase- 1 dependent IL-1 $\beta$ and 18 secretion [9]. Moreover, tetracyclines are able to inhibit MMPs by chelating $\mathrm{Zn}^{2+}$ ions from their active site [77]. Based on these mechanisms, tetracyclines decrease a variety of proinflammatory mediators downstream of the inflammasome-caspase-1 pathway and MMPs. Thus, they influence the alveolar capillary barrier integrity, prevent the breakdown of extracellular matrix and impair pulmonary neutrophil infiltration [78-83] (figure 2).

\section{Animal studies}

The reduced secretion of proinflammatory cytokines such as TNF- $\alpha$, IL-1 $1 \beta$, IL-6, IL-8 and IL-10 by doxycycline and chemically modified tetracycline 3 improved survival and ameliorated lung injury in animal models of secondary ARDS [84-87]. Of note, a recent study showed that tetracycline significantly limited both LPS- and influenza-induced lung injury in mice by inhibiting inflammasome-caspase-1 dependent IL-1 $\beta$ and IL-18 production [9]. Several studies have shown that tetracyclines downregulate the expression of gelatinases MMP-2 and -9 and NE, which correlates with a lower degree of lung injury and increased survival in animal models of sepsis-, pancreatitis-, cardiopulmonary-bypass induced ARDS and VILI [78, 80-83, 85, 87, 88]. In murine influenza-induced ARDS, tetracyclines markedly decreased MMPs but also biomarkers of epithelial and endothelial injury that are associated with decreased endothelial permeability and pulmonary injury [89-91].

McCANn et al. [92] have shown that chemically modified tetracycline 3, devoid of antibacterial activity, attenuates neutrophil sequestration in pigs. Although chemically modified tetracycline 3 had no effect on mononuclear sequestration, ARDS was prevented, supporting that neutrophil influx plays a key role in the pathogenesis of ARDS. Doxycycline also inhibited neutrophil influx in animal models of bacterial-, cardiopulmonary bypass- and pancreatitis-associated ARDS [79-82]. Prophylactic chemically modified tetracycline 3 treatment inhibited neutrophil infiltration, lowered the levels of NE and MMPs in BALF, thereby decreasing lung injury and improving survival in various animal models of indirect ARDS [78, 83, 93, 94].

\section{Human data}

In a recently published study, tetracycline inhibited the production of IL-1 $\beta$ and IL-18 by alveolar leucocytes obtained from patients with direct ARDS ex vivo [9]. Currently, a randomised clinical trial investigates whether doxycycline is able to reduce the proinflammatory response and thus the evolution towards ARDS in patients with COVID-19 (NCT04371952).

\section{Oxazolidinones}

As the first member of the oxazolidinones, linezolid exhibits antibacterial activity against Gram-positive bacteria via the inhibition of bacterial protein synthesis. It is mainly used as a last resort drug for severe infections caused by drug-resistant Gram-positive bacteria including methicillin-resistant Staphylococcus aureus (MRSA) and vancomycin-resistant enterococci [95].

\section{Mechanism of action}

Linezolid inhibits the secretion of proinflammatory mediators resulting in diminished chemotaxis of immune cells into the airways [96-98]. In particular, neutrophil migration, which is a hallmark of ARDS, is inhibited [97, 99]. Additionally, linezolid restores neutrophil effector mechanisms like phagocytosis and killing of pathogens while it suppresses phagocytosis in macrophages [100, 101]. Neutrophil apoptosis, which in combination with efferocytosis constitutes a crucial step toward ARDS resolution and is usually delayed in ARDS, is increased by linezolid [99].

\section{Animal studies}

Models of MRSA-induced lung injury

Several studies have investigated the effects of linezolid on the expression of inflammatory mediators in various animal models of MRSA-induced lung injury. AKInNusi et al. [96] have shown that linezolid and vancomycin display comparable effects in modulating the expression of MMP-9, IL-6 and MMP-5 in BALF and in regulating neutrophil influx in a murine model of MRSA-induced lung injury. Both antibiotics increased neutrophil apoptosis but had no effect on efferocytosis. However, linezolid in contrast to glycopeptides improved survival and alleviated lung injury by decreasing neutrophil infiltration and reducing levels of TNF- $\alpha$ in animal models of MRSA pneumonia [97, 98]. Furthermore, linezolid decreased levels of proinflammatory cytokines including IFN- $\gamma$, IL-1 $\beta$, IL-6, IL-12, IL-17 and the chemoattractant MIP-2 [97, 99-101]. 
Models of post-influenza secondary pulmonary infection

Influenza infection predisposes a host to secondary bacterial pneumonia with Staphylococcus aureus, Streptococcus pneumoniae and Haemophilus influenza and is a common cause of mortality [102]. An influenza-induced increase of IFN- $\gamma$ levels may lead to a hyporesponsiveness of innate immunity [103]. Other factors including a dysfunctional neutrophil response [104], an increase in IL-10 levels [105, 106] and the inhibition of alveolar macrophage phagocytosis by IFN- $\gamma$ may contribute to the susceptibility to secondary bacterial infection [107, 108]. By lowering IFN- $\gamma$ and TNF- $\alpha$ levels, BREsLow-Deckman et al. [103] demonstrated that prophylactic linezolid treatment decreased the susceptibility to post-influenza Streptococcus pneumonia-induced lung injury in mice. Although it did not reach statistical significance, the number of T-cells producing IL-10 was decreased which may be attributed to the activity of linezolid. Using a model of post-influenza MRSA-induced lung injury, Liu et al. [109] did not show an advantage for linezolid in modulating pulmonary innate immunity. In this study, linezolid, vancomycin and clindamycin all decreased IL-6, keratinocytes-derived chemokine (KC) and IFN- $\gamma$. In contrast, linezolid compared to vancomycin dampened neutrophil recruitment which was linked to reduced levels of chemotactic factors such as KC, MIP-2 and proinflammatory cytokines including IFN- $\gamma$, TNF- $\alpha$ and IL- $1 \beta$ in mice. Linezolid treatment protected mice from MRSA-induced lung injury and improved bacterial clearance [110]. In a recently published study, VERMA et al. [111] showed that linezolid in contrast to vancomycin ameliorated lung injury and improved survival in post-influenza MRSA pneumonia by reducing TNF- $\alpha$ and IL-6 levels.

\section{Human data}

Only a few ex vivo studies exist that describe the immunomodulatory effects of linezolid in humans. Linezolid significantly decreased the secretion of proinflammatory cytokines IL-1 $\beta$, IL-1 receptor antagonist, TNF- $\alpha$ and chemotactic factors including IL-6, IL-8 and CCL2 by human peripheral blood mononuclear cells after stimulation with LPS or MRSA respectively [112, 113]. This is consistent with studies showing that linezolid significantly reduced phagocytic activity of monocytes while vancomycin led to an increased phagocytosis in the same experimental setting [114]. Linezolid also inhibited the phagocytic activity of polymorphonuclear neutrophils (PMN) challenged with Staphylococcus aureus and Pseudomonas aeruginosa [115] in contrast to two other studies where linezolid did not influence the phagocytic activity of PMN against Gram-positive cocci [116, 117].

Linezolid reversed neutrophil dysfunction observed in critically ill patients, including those with VAP, which is related to increased levels of complement fragment C5a. Co-incubation of linezolid improved phagocytosis and killing of MRSA by dysfunctional human neutrophils isolated ex vivo (modelled by C5a-induced injury) [118].

\section{Fluoroquinolones}

Fluoroquinolones are an important class of broad-spectrum synthetic antimicrobial agents that inhibit DNA synthesis by targeting both the DNA gyrase and the topoisomerase IV enzymes [119]. The antimicrobial spectrum includes Gram-negative and Gram-positive bacteria including common respiratory pathogens, atypical pathogens and anaerobes [120]. Fluoroquinolones have been reported to exhibit anti-oxidative properties in vitro and in vivo [121, 122]. Moreover, they block the release of proinflammatory cytokines and chemokines resulting in impaired neutrophil chemotaxis [123-125].

The immunomodulatory effects of fluoroquinolones have been described for bacterial-, virus- and fungal-induced lung injury in various animal models [122, 123, 125, 126]. In bacterial-induced lung injury, not all fluoroquinolones seem to exhibit immunomodulatory effects. Results for moxifloxacin were contradictory. Moxifloxacin had no effect on cytokine production or the degree of lung injury in a murine pneumococcal pneumonia model [126]. However, in a murine model of pulmonary infection with Streptococcus pneumoniae and Pseudomonas aeruginosa, moxifloxacin decreased neutrophil influx and levels of proinflammatory cytokines (e.g. KC, IL-1 $\beta$, IL-17A) [123]. In LPS-induced lung injury only ciprofloxacin, but not moxifloxacin or levofloxacin, significantly decreased levels of TNF- $\alpha$, IL- $1 \beta$ and CXCL2/MIP-2 $\alpha$ and improved the degree of lung injury and survival [124]. Timing and frequency of doses likely influenced the results in the studies above. In the first study, mice received a similar dose of moxifloxacin but $24 \mathrm{~h}$ after infection with Streptococcus pneumoniae while in the other two studies moxifloxacin was applied prior to and after infection [123, 124, 126]. Moreover, the differing results may be attributed to their chemical structure and different pathogens. Immunomodulatory effects are particularly pronounced in fluoroquinolones with a cyclopropyl-moiety at position $\mathrm{N} 1$ of their quinolone ring like ciprofloxacin and moxifloxacin [127]. Furthermore, Gram-negative and Gram-positive bacteria seem to trigger cytokine production through different pathways which moxifloxacin may have a different impact on [128]. 
In pansorbin (heat-inactivated Staphylococcus aureus)-stimulated human monocytes, in contrast to LPS-stimulated human monocytes, moxifloxacin did not inhibit cytokine secretion [74].

Besides an excessive production of proinflammatory cytokines viral lung infections induce the generation of ROS and NO metabolites which are major contributors to the development of ARDS [129-131]. In an H1N1 influenza-induced ARDS mouse model it was shown that levofloxacin suppressed oxidative and nitrative stress (figure 2). Levofloxacin displayed a scavenging activity against neutrophil-derived ROS, thereby significantly reducing lung injury and increasing survival [122].

In addition to the investigation of the immunomodulatory effects of fluoroquinolones in LPS- and influenza-induced ARDS, a study on the effects of moxifloxacin on fungus-induced lung injury was performed. In immunocompromised mice pre-treated with moxifloxacin, levels of TNF- $\alpha$ and KC/CXCL1 remained low compared to an increase in TNF- $\alpha$ levels in the saline and ceftazidime group. Furthermore, they did not develop weight loss or Candida albicans pneumonia although moxifloxacin clearly does not exert fungicidal activity [125]. TNF- $\alpha$ acts as an important factor in the host defence against Candida albicans [132]. This was highlighted in a study where TNF- $\alpha$-deficient mice intravenously infected with Candida albicans died whereas wild-type mice survived [133].

To the best of our knowledge, no clinical studies on the immunomodulatory effects of fluoroquinolones in the treatment of ARDS have been published.

\section{Fosfomycin}

Fosfomycin is a phosphoenolpyruvate analogue representing an epoxid antibiotic class that inhibits an enzyme-catalysed reaction in the first step of bacterial cell wall synthesis of a broad spectrum of both Gram-positive and Gram-negative pathogens. Lately, there has been a revival of fosfomycin for the treatment of nosocomial infections due to multidrug resistance [134]. Fosfomycin possibly potentiates antibacterial effects by the induction of neutrophil phagocytosis and killing [135, 136].

The main immunomodulatory effects of fosfomycin are mediated by inhibiting TLR/NF-кb/MAPK signalling pathways [137, 138]. Fosfomycin further diminishes NLRP3 inflammasome activation [138]. These effects combined lead to a reduction of proinflammatory cytokine synthesis [137-139].

In a rat model of sepsis-induced lung injury, fosfomycin decreased the expression of TLR-4, NF- $\kappa b$ and TNF- $\alpha$ in lung tissue. Fosfomycin also exhibited antioxidative properties in this setting [137]. Fosfomycin significantly reduced the phosphorylation of MAPK, the expression of NLRP3 inflammasome components and subsequently the release of IL-1 $\beta$ and IL-18. As a result, the alveolar capillary integrity was protected, less pulmonary oedema occurred, and overall lung injury was significantly ameliorated [138].

Little is known about the immunomodulatory effects of fosfomycin in human ARDS. In a recently published study, IL-6 was significantly decreased by fosfomycin in human LPS-stimulated PMN. Proinflammatory cytokines were also significantly reduced in human ex vivo models of endotoxemia [140, 141]. However, in a human in vivo model of endotoxemia, proinflammatory cytokines were not influenced. This can probably be explained by the study design, a major limitation, which cannot fully mimic septic shock [142].

\section{Future research perspectives}

Our understanding of the key mechanisms underlying the immunomodulatory properties of antibiotics has grown tremendously since the 1990s. Yet, further research is warranted before antibiotics as immunomodulators can be implemented into daily clinical practice. The INCLASS phase 3 multicentre study (NCT03345992), which is investigating the benefit of clarithromycin in patients with sepsis-induced respiratory distress syndrome, has recently been completed. Two randomised controlled trials are currently examining if clarithromycin is capable of attenuating the proinflammatory host response in community-acquired pneumonia (NCT04724044) and influenza infection (NCT03824847).

One of the limitations regarding the routine clinical use of immunomodulatory antibiotics in the near future is the development of antibiotic resistance. The fear of inducing antimicrobial resistance might restrict the routine use of antibiotics for immunomodulatory purposes in ARDS and other inflammatory diseases. Non-antibiotic drugs such as the erythromycin derivatives EM703 and EM900, the azithromycin derivative CSY0073 and the tetracycline derivative CMT-3 could represent a solution to overcome this problem. The immunomodulatory effects of these derivatives have already been investigated in preclinical studies [62, 86, 94, 143, 144]. In comparison to azithromycin, CSY0073 exhibited an equivalent anti-inflammatory 
TABLE 1 Immunomodulatory effects of antibiotics in acute respiratory distress syndrome (ARDS) and lung injury models

\begin{tabular}{|c|c|c|c|c|c|c|c|c|c|c|}
\hline & Antibiotic & Model & Specimen & Stimulants or pathogens & Immunomodulatory effects & $\begin{array}{l}\text { Neutrophil } \\
\text { influx }\end{array}$ & $\begin{array}{l}\text { Endothelial } \\
\text { permeability }\end{array}$ & $\begin{array}{l}\text { Degree of } \\
\text { lung injury }\end{array}$ & Survival & Reference \\
\hline \multirow[t]{20}{*}{ Macrolides } & AZM & $\begin{array}{l}\text { Human } \\
(\text { RCT })\end{array}$ & $\begin{array}{l}\text { Nasal and } \\
\text { endotracheal } \\
\text { samples }\end{array}$ & RSV & $\begin{array}{l}\text { MMP-9, IL-1, IL-10, TNF- } \alpha \\
\text { (endotracheal) } \downarrow \text {, nasal } \Leftrightarrow\end{array}$ & NA & NA & NA & NA & Kong et al. [71] \\
\hline & AZM & Mouse & $\begin{array}{l}\text { Macrophages } \\
\quad(\mathrm{J} 774)\end{array}$ & LPS & $\begin{array}{c}\text { M2 macrophages (via } \\
\text { inhibition of NF-KB STAT1 } \\
\text { pathways) } \downarrow\end{array}$ & NA & NA & NA & NA & HAYDAR et al. [33] \\
\hline & CAM & Mouse & $\begin{array}{l}\text { BALF, lung tissue, } \\
\text { serum }\end{array}$ & $\begin{array}{l}\text { H1N1 influenza virus, } \\
\text { S. pneumoniae i.n. }\end{array}$ & $\begin{array}{c}\text { IFN- } \gamma \downarrow \text {, IL-10 } \uparrow \\
\text { CD11b+Gr-1+ MDSC-like cells } \\
\text { (via STAT3 pathway) } \uparrow\end{array}$ & $\downarrow$ & ND & ND & $\uparrow$ & $\begin{array}{c}\text { Namkoong et al. } \\
\text { [39] }\end{array}$ \\
\hline & AZM & Mouse & BALF, lung tissue & RSV i.n. & IL-5, IL-6, IFN- $\gamma \downarrow$ & $\Leftrightarrow$ & ND & $\downarrow$ & $\uparrow$ & $\begin{array}{c}\text { Mosquera et al. } \\
{[41]}\end{array}$ \\
\hline & AZM & Mouse & Lung tissue & H1N1 influenza virus i.n. & IL-6, TNF- $\alpha \Leftrightarrow$ & ND & ND & ND & $\Leftrightarrow$ & FAGE et al. [64] \\
\hline & AZM & Mouse & $\begin{array}{l}\text { BALF, lung tissue, } \\
\text { blood plasma }\end{array}$ & Radiation & $\begin{array}{c}\text { IL-1 } \beta, \text { IL-6, TNF- } \alpha \text {, TGF- } \beta 1 \text {, } \\
\alpha \text {-SMA, COL1A1 } \downarrow \text {, oxidative } \\
\text { damage (lipid peroxidation) } \downarrow\end{array}$ & ND & ND & $\downarrow$ & ND & TANG et al. [40] \\
\hline & AZM & Mouse & BALF, lung tissue & P. aeruginosa i.t. & $\begin{array}{c}\text { Caspase-1 activation } \downarrow \text {, IL-1 } \\
\text { cleavage } \downarrow \\
\text { IL-1 } 1 \beta, \mathrm{IL}-18 \downarrow\end{array}$ & $\downarrow$ & $\downarrow$ & $\downarrow$ & ND & FAn et al. [30] \\
\hline & AZM & $\begin{array}{l}\text { Human } \\
\text { (cohort } \\
\text { study) }\end{array}$ & $\begin{array}{l}\text { Blood plasma, } \\
\text { PBMCs }\end{array}$ & H3N2 influenza virus & $\begin{array}{l}\text { IL-6, CXCL8, IL-17, CXCL9, } \\
\text { sTNFR-1, IL-18, IFN- } \gamma, \text { IP-10 }\end{array}$ & ND & ND & ND & ND & LEE et al. [42] \\
\hline & AZM & $\begin{array}{l}\text { Human } \\
\text { (cohort } \\
\text { study) }\end{array}$ & Blood plasma, BALF & $\begin{array}{l}\text { Community-acquired } \\
\text { pneumonia }\end{array}$ & $\begin{array}{l}\text { IL-6, TNF- } \alpha \text { (plasma) } \downarrow \text {, IL-8, } \\
\text { IL-10 (BALF) } \downarrow\end{array}$ & ND & ND & ND & ND & $\begin{array}{l}\text { LoREnzo et al. } \\
{[70]}\end{array}$ \\
\hline & $\begin{array}{l}\text { CSY0073, } \\
\text { AZM }\end{array}$ & Mouse & $\begin{array}{l}\text { BALF, lung tissue, } \\
\text { alveolar } \\
\text { macrophages, BEC }\end{array}$ & LPS i.n. & $\begin{array}{c}\text { TNF- } \alpha, \text { CXCL1, CXCL2, IL-6, } \\
\text { IL-1 } 1 \beta \downarrow\end{array}$ & $\downarrow$ & ND & ND & ND & Ballor et al. [144] \\
\hline & AZM & Mouse & BALF & LPS i.t. & $\begin{array}{c}\text { NF-kB, TNF- } \alpha, \text { G-CSF, IL-6, IL-9, } \\
\text { MCP- } 1 \downarrow\end{array}$ & $\downarrow$ & ND & ND & ND & $\begin{array}{l}\text { SteLLARI et al. } \\
\text { [35] }\end{array}$ \\
\hline & CAM & Mouse & BALF, lung tissue & Ventilation & 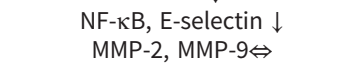 & $\downarrow$ & $\Leftrightarrow$ & $\downarrow$ & ND & $\begin{array}{l}\text { Amado-RodRíGuez } \\
\text { et al. [36] }\end{array}$ \\
\hline & AZM & Mouse & BALF, lung tissue & A. baumanii i.b. & $\begin{array}{c}\text { IL-1 } \beta, \text { IL-6, MIP-2, } \\
\text { macrophages, lymphocytes } \downarrow\end{array}$ & $\downarrow$ & ND & $\downarrow$ & $\uparrow$ & YAMADA et al. [48] \\
\hline & CAM & $\begin{array}{l}\text { Human } \\
\text { (in vitro) }\end{array}$ & $\begin{array}{l}\text { Alveolar epithelial } \\
\text { cells (A549) }\end{array}$ & RSV, S. pneumoniae & $\begin{array}{l}\text { IL-6, IL-8, CCL5/Rantes } \downarrow \\
\text { PAF receptor expression } \downarrow\end{array}$ & NA & NA & NA & NA & ҮокотА et al. [51] \\
\hline & CAM & $\begin{array}{l}\text { Human } \\
\text { (RCT) }\end{array}$ & $\begin{array}{l}\text { Monocytes, } \\
\text { neutrophils }\end{array}$ & $\begin{array}{l}\text { Ventilator-associated } \\
\text { pneumonia }\end{array}$ & 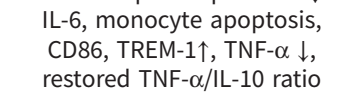 & ND & ND & ND & ND & SPYRIDAKI et al. [8] \\
\hline & AZM & Mouse & $\begin{array}{l}\text { BALF, lung tissue, } \\
\text { macrophages } \\
(\mathrm{J} 774)\end{array}$ & LPS i.n. & $\begin{array}{c}\text { IL- } 1 \beta \downarrow \text { by inhibition of AP-1 } \\
\text { activation, NF-kB, ERK-1 } \\
\text { and }-2 \Leftrightarrow\end{array}$ & $\downarrow$ & ND & $\downarrow$ & ND & Bosnar et al. [31] \\
\hline & AZM & Mouse & BALF, lung tissue & P. aeruginosa i.t. & $\begin{array}{l}\text { TNF- } \alpha, \text { IL-6, CCL2 } \downarrow \text {, IFN- } \gamma, \\
\text { IL-10, IL-12p70 } \Leftrightarrow, \mathrm{M} 2 \\
\text { macrophages, arginase1, } \\
\text { mannose receptor, CD11b+Gr-1 } \\
+ \text { MDSC-like cells } \uparrow\end{array}$ & $\Leftrightarrow$ & ND & ND & $\Leftrightarrow$ & FEoLA et al. [38] \\
\hline & CAM & Mouse & BALF, lung tissue & H. influenzae i.t. & 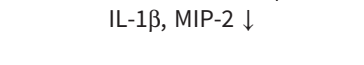 & $\downarrow$ & ND & $\downarrow$ & ND & $\begin{array}{c}\text { Nakamura et al. } \\
\text { [47] }\end{array}$ \\
\hline & CAM & $\begin{array}{l}\text { Human } \\
\text { (in vitro) }\end{array}$ & $\begin{array}{l}\text { Tracheal epithelial } \\
\text { cells }\end{array}$ & H3N2 influenza virus & $\begin{array}{c}\text { IL-1 } \beta, \text { IL-6, IL-8, NF-kB (p50, } \\
\text { p65) } \downarrow\end{array}$ & NA & NA & NA & NA & YAmAYA et al. [34] \\
\hline & AZM, CAM & Mouse & $\begin{array}{l}\text { BALF, lung tissue, } \\
\text { macrophages } \\
(\mathrm{J} 774)\end{array}$ & LPS i.n. & $\begin{array}{l}\text { MCP-1/CCL2, GM-CSF, IL-1 } \beta \text {, } \\
\text { TNF- } \alpha \text {, E-selectin, MPO } \\
\text { concentration } \downarrow \text { CXCL1, } \\
\text { CXCL2 } \Leftrightarrow\end{array}$ & $\downarrow$ & ND & ND & ND & Bosnar et al. [43] \\
\hline
\end{tabular}




\begin{tabular}{|c|c|c|c|c|c|c|c|c|c|c|}
\hline & Antibiotic & Model & Specimen & Stimulants or pathogens & Immunomodulatory effects & $\begin{array}{l}\text { Neutrophil } \\
\text { influx }\end{array}$ & $\begin{array}{l}\text { Endothelial } \\
\text { permeability }\end{array}$ & $\begin{array}{l}\text { Degree of } \\
\text { lung injury }\end{array}$ & Survival & Reference \\
\hline & CAM & Mouse & $\begin{array}{l}\text { BALF, lung tissue, } \\
\text { alveolar } \\
\text { macrophages }\end{array}$ & K. pneumoniae i.n. & $\begin{array}{l}\text { Oxidative damage (NO, MDA, } \\
\text { MPO) } \downarrow \text {, macrophage } \\
\text { phagocytic activity } \uparrow\end{array}$ & $\downarrow$ & ND & $\downarrow$ & ND & Kumar et al. [44] \\
\hline & AZM & Mouse & $\begin{array}{l}\text { Macrophages } \\
\quad \text { ( J774) }\end{array}$ & LPS & $\begin{array}{l}\text { M2 macrophages } \uparrow(\text { IL-10, } \\
\text { IL-23, mannose receptor, CD23 } \\
\uparrow ; \text { IL-6, IL-12, CCR7, iNOS } \downarrow)\end{array}$ & NA & NA & NA & NA & MuRPHy et al. [56] \\
\hline & AZM & $\begin{array}{l}\text { Human } \\
\text { (ex vivo) }\end{array}$ & PBEC & LPS & IL-8, GM-CSF $\downarrow$, VEGF $\Leftrightarrow$ & NA & NA & NA & NA & MuRPHy et al. [49] \\
\hline & EM703 & Mouse & BALF, lung tissue & Bleomycin i.v. & $\begin{array}{l}\text { TGF- } \beta \text {, macrophages, } \\
\text { fibroblasts } \downarrow\end{array}$ & $\downarrow$ & ND & $\downarrow$ & ND & Li et al. [62] \\
\hline & AZM & Mouse & Lung tissue & P. aeruginosa i.t. & $\begin{array}{l}\text { KC/CXCL1, TNF- } \alpha \downarrow \text {, inhibition } \\
\text { of ERK- } 1 \text { and }-2 \text { activation }\end{array}$ & $\downarrow$ & ND & ND & ND & TsAl et al. [46] \\
\hline & CAM & Mouse & BALF, lung tissue & M. pneumoniae i.n. & $\begin{array}{l}\text { IFN- } \gamma, \text { TNF- } \alpha, \text { IL-6, KC/CXCL1, } \\
\text { MIP- } 1 \alpha, \text { MCP-1 } \downarrow\end{array}$ & ND & ND & $\downarrow$ & ND & HARDY et al. [50] \\
\hline & $\begin{array}{l}\text { CAM, RXM, } \\
\text { AZM, JM }\end{array}$ & Mouse & BALF, lung tissue & Bleomycin i.t. & $\begin{array}{l}\text { KC/CXCL1 } \downarrow \text { (RXM, CAM), } \\
\text { apoptosis of bronchial and } \\
\text { alveolar epithelial cells } \downarrow \\
\text { (RXM>CAM>AZM) }\end{array}$ & $\begin{array}{c}\downarrow(\mathrm{RXM}> \\
\mathrm{CAM}>\mathrm{AZM}) \\
\mathrm{JM} \Leftrightarrow\end{array}$ & $\begin{array}{c}\downarrow(R X M> \\
\text { CAM>AZM), JM } \\
\Leftrightarrow\end{array}$ & $\begin{array}{c}\downarrow(\mathrm{RXM}> \\
\mathrm{CAM}>\mathrm{AZM}) \\
\mathrm{JM} \Leftrightarrow\end{array}$ & ND & $\begin{array}{c}\text { KaWASHIMA et al. } \\
{[45]}\end{array}$ \\
\hline & ERM & Mouse & $\begin{array}{c}\text { BALF, serum, } \\
\text { macrophages (RAW } \\
264.7 \text { ) }\end{array}$ & $\begin{array}{l}\text { H2N2 influenza virus } \\
\text { nebulisation }\end{array}$ & $\begin{array}{l}\text { IFN- } \gamma \text {, NO metabolites (nitrite, } \\
\text { nitrate) } \downarrow \text {, macrophages, } \\
\text { lymphocytes } \downarrow\end{array}$ & $\Leftrightarrow$ & ND & ND & $\uparrow$ & SAто et al. [63] \\
\hline Ketolides & TEL & Mouse & $\begin{array}{l}\text { BALF, macrophages } \\
\text { (RAW 264.7), } \\
\text { epithelial cells } \\
\text { (MLE-12) }\end{array}$ & LPS nebulisation & Nitrite, MIP-2, TNF- $\alpha \downarrow$ & $\downarrow$ & $\downarrow$ & ND & ND & LeIVA et al [75] \\
\hline \multirow[t]{10}{*}{ Tetracyclines } & TET & $\begin{array}{l}\text { Mouse, } \\
\text { human } \\
\text { (ex vivo) }\end{array}$ & $\begin{array}{c}\text { BALF, BMDM; } \\
\text { alveolar leucocytes }\end{array}$ & $\begin{array}{l}\text { LPS, H1N1 influenza virus } i . \\
t . \text { (mouse); viral, bacterial } \\
\text { and non-pulmonary ARDS } \\
\text { (human) }\end{array}$ & $\begin{array}{c}\text { IL- } 1 \beta, \text { IL- } 18 \text {, caspase- } 1 \\
\text { activation } \downarrow\end{array}$ & $\downarrow$ & ND & $\downarrow$ & $\downarrow$ & Peukert et al. [9] \\
\hline & DOX & Mouse & $\begin{array}{l}\text { Lung tissue, blood } \\
\text { plasma }\end{array}$ & $\begin{array}{l}\text { Caecal ligation and } \\
\text { puncture }\end{array}$ & TNF- $\alpha$, IL-1 $\beta$, IL-6, MPO $\downarrow$ & ND & ND & ND & $\uparrow$ & Patel et al [84] \\
\hline & DOX & Mouse & $\begin{array}{l}\text { BALF, lung tissue, } \\
\text { serum }\end{array}$ & Paraquat i.t. & MMP-9, MPO $\downarrow$ & $\downarrow$ & ND & $\downarrow$ & ND & ZHANG et al. [147] \\
\hline & DOX & Rat & $\begin{array}{l}\text { BALF, lung tissue, } \\
\text { blood plasma }\end{array}$ & Cardiopulmonary bypass & TNF- $\alpha$, IL-1 $\beta$, MMP-9 $\downarrow$ & ND & $\downarrow$ & $\downarrow$ & ND & WANG et al. [85] \\
\hline & DOX & Dog & $\begin{array}{l}\text { BALF, lung tissue, } \\
\text { blood plasma }\end{array}$ & Cardiopulmonary bypass & MMP-9, MPO $\downarrow$ & $\downarrow$ & $\downarrow$ & $\downarrow$ & ND & ZHANG et al. [82] \\
\hline & CMT-3 & Pig & $\begin{array}{l}\text { BALF, lung tissue, } \\
\text { blood plasma }\end{array}$ & $\begin{array}{l}\text { Ischaemia by clamping of } \\
\text { SMA, placement of faecal } \\
\text { clot in peritoneum }\end{array}$ & $\begin{array}{c}\text { TNF- } \alpha, \text { IL-1 } 1 \beta, \text { II-6, IL-8, IL-10 } \downarrow \\
\text { MMP- } 2,-9, \text { NE } \Leftrightarrow\end{array}$ & ND & $\Leftrightarrow$ & $\downarrow$ & $\Leftrightarrow$ & Ror et al. [86] \\
\hline & DOX & Mouse & BALF, lung tissue & H3N2 influenza virus i.n. & $\begin{array}{l}\text { MMP-2, MMP-9, T1- } \alpha \text {, } \\
\text { thrombomodulin } \downarrow\end{array}$ & $\downarrow$ & $\downarrow$ & $\downarrow$ & ND & NG et al. [91] \\
\hline & DOX & Mouse & BALF, lung tissue & LPS i.t. & $\begin{array}{l}\text { Syndecan-1 (substrate of } \\
\text { MMP-7) } \downarrow\end{array}$ & $\downarrow$ & $\Leftrightarrow$ & $\downarrow$ & ND & Moon et al. [79] \\
\hline & CMT-3 & Sheep & $\begin{array}{l}\text { Lung tissue, blood } \\
\text { plasma }\end{array}$ & $\begin{array}{l}\text { Third-degree burn, smoke } \\
\text { inhalation, barotrauma } \\
\text { injuries }\end{array}$ & MMP-2 $\downarrow$, MMP-9 $\Leftrightarrow$ & ND & ND & $\downarrow$ & $\uparrow$ & ZHou et al. [94] \\
\hline & DOX & Rat & Lung tissue & $\begin{array}{l}\text { Acute pancreatitis } \\
\text { (intraductal } \\
\text { glycodesoxycholic acid, } \\
\text { cerulein i.v.) }\end{array}$ & MMP-9 $\downarrow$ & $\downarrow$ & $\downarrow$ & $\downarrow$ & ND & SocHOR et al. [80] \\
\hline
\end{tabular}




\begin{tabular}{|c|c|c|c|c|c|c|c|c|c|c|}
\hline & Antibiotic & Model & Specimen & Stimulants or pathogens & Immunomodulatory effects & $\begin{array}{l}\text { Neutrophil } \\
\text { influx }\end{array}$ & $\begin{array}{l}\text { Endothelial } \\
\text { permeability }\end{array}$ & $\begin{array}{l}\text { Degree of } \\
\text { lung injury }\end{array}$ & Survival & Reference \\
\hline & DOX & Mouse & BALF, lung tissue & LPS or S. pneumoniae i.t. & MMP-2, $-9 \downarrow$ & $\downarrow$ & ND & $\downarrow$ & $\uparrow$ & FuJITA et al. [81] \\
\hline & CMT-3 & Rat & BALF, lung tissue & Ventilation & MMP-9, MPO $\downarrow$ & $\downarrow$ & $\downarrow$ & $\downarrow$ & ND & KIm et al. [88] \\
\hline & CMT-3 & Pig & $\begin{array}{l}\text { BALF, lung tissue, } \\
\text { serum, blood } \\
\text { plasma }\end{array}$ & $\begin{array}{l}\text { Ischaemia by clamping of } \\
\text { SMA Placement of faecal } \\
\text { clot in peritoneum }\end{array}$ & $\begin{array}{l}\text { IL-6, IL-8, IL-10, NE } \downarrow \text {, } \\
\text { IL-1, MMP-2, }-9 \Leftrightarrow\end{array}$ & $\Leftrightarrow$ & ND & $\downarrow$ & $\uparrow$ & $\begin{array}{c}\text { STEINBERG et al. } \\
\text { [87] }\end{array}$ \\
\hline & CMT-3 & Rat & $\begin{array}{l}\text { BALF, lung tissue, } \\
\text { serum }\end{array}$ & $\begin{array}{l}\text { Caecal ligation and } \\
\text { puncture }\end{array}$ & MMP-2, MMP-9 $\downarrow$ & ND & $\downarrow$ & $\downarrow$ & $\uparrow$ & $\begin{array}{c}\text { SteinBeRg et } a l . \\
{[78]}\end{array}$ \\
\hline & CMT-3 & Pig & BALF, lung tissue & LPS i.v. & MMP-2, MMP-9 $\downarrow$ & $\downarrow$ & $\downarrow$ & $\downarrow$ & ND & CARNEY et al. [93] \\
\hline & CMT-3 & Pig & Lung tissue & $\begin{array}{c}\text { Cardiopulmonary bypass, } \\
\text { LPS i.v. }\end{array}$ & ND & $\downarrow$ & ND & ND & ND & $\begin{array}{l}\text { McCann et al. } \\
\text { [92] }\end{array}$ \\
\hline & CMT-3 & Pig & BALF, lung tissue & $\begin{array}{c}\text { Cardiopulmonary bypass, } \\
\text { LPS i.v. }\end{array}$ & MMP-2, NE $\downarrow$ & $\downarrow$ & $\downarrow$ & $\downarrow$ & ND & CARneY et al. [83] \\
\hline \multirow[t]{16}{*}{ Oxazolidinones } & LZD & $\begin{array}{l}\text { Human } \\
\text { (ex vivo) }\end{array}$ & Neutrophils & C5a, MRSA & $\begin{array}{l}\text { Neutrophil phagocytosis and } \\
\text { killing } \uparrow \text {, respiratory burst, } \\
\text { neutrophil transmigration } \Leftrightarrow\end{array}$ & NA & NA & NA & NA & Evans et al. [118] \\
\hline & LZD & Mouse & BALF & $\begin{array}{l}\text { H1N1 influenza virus, MRSA } \\
\text { i.n. }\end{array}$ & TNF- $\alpha$, IL-6 $\downarrow$ & ND & $\downarrow$ & $\downarrow$ & $\uparrow$ & VERMA et al. [111] \\
\hline & LZD & Rabbit & $\begin{array}{l}\text { Lung tissue, whole } \\
\text { blood }\end{array}$ & MRSA i.n. & TNF- $\alpha \downarrow$ & ND & ND & $\downarrow$ & ND & $\begin{array}{c}\text { PaUchaRd et al. } \\
{[100]}\end{array}$ \\
\hline & LZD & Mouse & $\begin{array}{l}\text { BALF, lung tissue, } \\
\text { alveolar } \\
\text { macrophages }\end{array}$ & $\begin{array}{l}\text { H1N1 influenza virus i.n., } \\
\text { MRSA i.t. }\end{array}$ & $\begin{array}{c}\text { KC/CXCL1, MIP-2, IFN- } \gamma, \\
\text { TNF- } \alpha, \text { IL- } 1 \beta \downarrow\end{array}$ & $\downarrow$ & $\downarrow$ & $\downarrow$ & ND & BHAN et al. [110] \\
\hline & LZD & $\begin{array}{l}\text { Human } \\
\text { (in vitro) }\end{array}$ & THP-1 monocytes & LPS & $\begin{array}{c}\text { TLR-1, }-2,-6 \uparrow, \text { phagocytic } \\
\text { activity } \downarrow\end{array}$ & NA & NA & NA & NA & Bode et al. [114] \\
\hline & LZD & Mouse & Lung tissue & MRSA t.t. & TNF- $\alpha$, IL-1 $\beta$, MIP- $2 \downarrow$ & $\downarrow$ & $\downarrow$ & $\downarrow$ & ND & $\begin{array}{c}\text { JACQUELINE et al. } \\
{[97]}\end{array}$ \\
\hline & LZD & Mouse & BALF, lung tissue & MRSA i.n. & 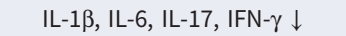 & ND & $\downarrow$ & $\downarrow$ & $\uparrow$ & CHEN et al. [99] \\
\hline & LZD & Mouse & Lung tissue & $\begin{array}{l}\text { H1N1 influenza virus, } \\
\text { MRSA i.n. }\end{array}$ & $\begin{array}{c}\text { IFN- } \gamma, \text { KC/CXCL1, IL-6 } \downarrow \text {, IL-1 } 1, \\
\text { TNF- } \alpha, \text { IL-12 } \Leftrightarrow\end{array}$ & ND & ND & ND & ND & Liv et al. [109] \\
\hline & LZD & Mouse & $\begin{array}{l}\text { BALF, lung tissue, } \\
\text { TBLN }\end{array}$ & $\begin{array}{l}\text { H1N1 influenza virus, } \\
\text { S. pneumoniae i.n. }\end{array}$ & IFN- $\gamma$, TNF- $\alpha \downarrow$ & ND & ND & ND & ND & $\begin{array}{c}\text { BRESLOW-DECKMAN } \\
\text { et al. [103] }\end{array}$ \\
\hline & LZD & $\begin{array}{l}\text { Human } \\
\text { (ex vivo) }\end{array}$ & Whole blood & MRSA & IL-6, IL-8, MCP-1 $\downarrow$ & NA & NA & NA & NA & $\begin{array}{l}\text { Franks et al. } \\
\quad[113]\end{array}$ \\
\hline & LZD & Mouse & Lung tissue & MRSA i.n. & TNF- $\alpha$, IL-6, IL-12 $\downarrow$ & ND & ND & ND & ND & $\begin{array}{l}\text { YoshizAWA et al. } \\
\text { [101] }\end{array}$ \\
\hline & LZD & Mouse & $\begin{array}{l}\text { BALF, lung tissue, } \\
\text { alveolar } \\
\text { macrophages }\end{array}$ & MRSA t.t. & $\begin{array}{l}\text { MCP-5, IL-6, MMP-9 } \downarrow \text {, } \\
\text { neutrophil apoptosis } \uparrow \text {, } \\
\text { efferocytosis } \Leftrightarrow\end{array}$ & $\downarrow$ & ND & $\downarrow$ & ND & $\begin{array}{l}\text { AkinNusi et al. } \\
{[96]}\end{array}$ \\
\hline & LZD & Piglet & $\begin{array}{l}\text { BALF, lung tissue, } \\
\text { serum, blood } \\
\text { plasma }\end{array}$ & MRSA i.t. & TNF- $\alpha$, IL- $6 \Leftrightarrow$ & ND & ND & $\downarrow$ & $\uparrow$ & Luna et al. [98] \\
\hline & LZD & Mouse & Lung tissue & MRSA i.v. & TNF- $\alpha$, IL-1 $\beta$, MIP-2 $\downarrow$ & ND & ND & $\downarrow$ & $\uparrow$ & $\begin{array}{c}\text { YANAGIHARA et al. } \\
\text { [148] }\end{array}$ \\
\hline & LZD & $\begin{array}{l}\text { Human } \\
\text { (ex vivo) }\end{array}$ & PBMC & LPS & IL-1 $\beta$, IL-6, TNF- $\alpha$, IL-1RA $\downarrow$ & NA & NA & NA & NA & $\begin{array}{l}\text { GARCIA-RoccA } \\
\text { et al. [112] }\end{array}$ \\
\hline & LZD & $\begin{array}{l}\text { Human } \\
\text { (ex vivo) }\end{array}$ & PMN & MRSA, MSSA, VRE & $\begin{array}{l}\text { Phagocytosis, production of } \\
\text { superoxide, hydrogen } \\
\text { peroxidase radicals } \Leftrightarrow\end{array}$ & NA & NA & NA & NA & $\begin{array}{l}\text { BALLESTA et al. } \\
\quad[116]\end{array}$ \\
\hline Fluoroquinolones & LVFX & Murine & $\begin{array}{l}\text { BALF, lung tissue, } \\
\text { blood }\end{array}$ & H1N1 influenza virus i.t. & $\begin{array}{l}\text { IFN- } \gamma \text {, TNF- } \alpha \downarrow \text {, oxidative and } \\
\text { nitrative stress: NO } \\
\text { metabolites, ROS } \downarrow\end{array}$ & ND & ND & $\downarrow$ & $\uparrow$ & ENoKI et al. [122] \\
\hline
\end{tabular}


TABLE 1 Continued

\begin{tabular}{|c|c|c|c|c|c|c|c|c|c|c|}
\hline & Antibiotic & Model & Specimen & Stimulants or pathogens & Immunomodulatory effects & $\begin{array}{l}\text { Neutrophil } \\
\text { influx }\end{array}$ & $\begin{array}{l}\text { Endothelial } \\
\text { permeability }\end{array}$ & $\begin{array}{l}\text { Degree of } \\
\text { lung injury }\end{array}$ & Survival & Reference \\
\hline & MOX & $\begin{array}{l}\text { Human } \\
\text { (ex vivo), } \\
\text { mouse }\end{array}$ & $\begin{array}{l}\text { BALF, lung tissue, } \\
\text { blood plasma }\end{array}$ & S. pneumoniae i.n. & IL-6, IL-8, IL-1 $\beta$, KC/CXCL1 $\Leftrightarrow$ & ND & $\downarrow$ & $\Leftrightarrow$ & ND & $\begin{array}{l}\text { MüLLER-REDETZKY } \\
\text { et al. [126] }\end{array}$ \\
\hline & MOX & Mouse & $\begin{array}{l}\text { BALF, lung tissue, } \\
\text { blood plasma }\end{array}$ & $\begin{array}{l}\text { S. pneumoniae, } \\
\text { P. aeruginosa i.n. }\end{array}$ & $\begin{array}{c}\text { IL-1 } \beta, \text { KC/CXCL1, IL-17A } \downarrow \text {, } \\
\text { TNF- } \alpha \text { expression in lung } \\
\text { tissue } \downarrow\end{array}$ & $\downarrow$ & ND & $\downarrow$ & ND & $\begin{array}{c}\text { BEISSWENGER et al. } \\
{[123]}\end{array}$ \\
\hline & $\begin{array}{c}\text { CPFX, } \\
\text { LVFX, MOX }\end{array}$ & Mouse & BALF, serum & LPS i.t. & TNF- $\alpha$, IL-1 $1 \beta$, MIP-2 $\downarrow$ (CPFX) & ND & $\begin{array}{l}\downarrow \text { (CPFX), } \Leftrightarrow \\
\text { LVFX, MOX }\end{array}$ & $\begin{array}{l}\downarrow \text { (CPFX), } \Leftrightarrow \\
\text { LVFX, MOX }\end{array}$ & $\begin{array}{l}\downarrow \text { (CPFX), } \\
\Leftrightarrow \text { LVFX, } \\
\quad \text { MOX }\end{array}$ & HUANG et al. [124] \\
\hline & MOX & Mouse & Lung tissue & $\begin{array}{l}\text { C. albicans i.t., } \\
\text { cyclophosphamide i.p. }\end{array}$ & $\begin{array}{l}\text { TNF- } \alpha, \mathrm{KC} / \mathrm{CXCL} 1 \downarrow \\
\text { IL-2, IL-10, IFN- } \gamma \Leftrightarrow\end{array}$ & ND & ND & $\downarrow$ & $\uparrow$ & ShaLit et al. [125] \\
\hline \multirow[t]{8}{*}{$\begin{array}{l}\text { Epoxid antibiotic } \\
\text { fosfomycin }\end{array}$} & FOM & Rat & Lung tissue & $\begin{array}{l}\text { Caecal ligation and } \\
\text { puncture }\end{array}$ & $\begin{array}{c}\text { TLR-4, NF-KB, TNF- } \alpha \text {, oxidative } \\
\text { damage (TBARS } \downarrow,-S H \uparrow \text { ) } \downarrow\end{array}$ & ND & ND & $\uparrow$ & ND & YILDIz et al. [137] \\
\hline & FOM & $\begin{array}{l}\text { Human } \\
\text { (ex vivo) }\end{array}$ & PMN & LPS & IL-6 $\downarrow$ & NA & NA & NA & NA & $\begin{array}{l}\text { UBUGAl et al. } \\
\text { [149] }\end{array}$ \\
\hline & FOM & $\begin{array}{l}\text { Human } \\
\text { (in vitro), } \\
\text { mouse }\end{array}$ & $\begin{array}{l}\text { THP-1 monocytes, } \\
\text { alveolar epithelial } \\
\text { cells (MLE-12), lung } \\
\text { tissue, BALF }\end{array}$ & S. aureus i.v. & $\begin{array}{c}\text { MAPK ( JNK, ERK, p38), NLRP3 } \\
\text { proteins and activation, IL-13, } \\
\text { IL-18, MPO } \downarrow\end{array}$ & $\downarrow$ & $\downarrow$ & $\uparrow$ & ND & An et al. [138] \\
\hline & FOM & $\begin{array}{l}\text { Human } \\
\text { (cohort } \\
\text { study) }\end{array}$ & Whole blood & LPS & TNF- $\alpha$, IL-1 $\beta$, IL- $6 \Leftrightarrow$ & NA & NA & NA & NA & $\begin{array}{c}\text { SAUERMANn et al. } \\
{[142]}\end{array}$ \\
\hline & FOM & $\begin{array}{l}\text { Human } \\
\text { (ex vivo) }\end{array}$ & Whole blood & LPS & $\begin{array}{l}\text { TNF- } \alpha \text {, IL-1 } 1 \beta, \text { IL-6 } \downarrow \text {, } \\
\text { IL-4, IL-10, IL-13 } \Leftrightarrow\end{array}$ & NA & NA & NA & NA & $\begin{array}{l}\text { ZEITLINGER et al. } \\
{[140]}\end{array}$ \\
\hline & FOM & Mouse & Serum & LPS & TNF- $\alpha$, IL-1 $1 \beta \downarrow$ & NA & NA & NA & NA & $\begin{array}{l}\text { Matsumoto et al. } \\
{[139]}\end{array}$ \\
\hline & FOM & $\begin{array}{l}\text { Human } \\
\text { (ex vivo) }\end{array}$ & Monocytes & LPS & $\begin{array}{c}\text { TNF- } \alpha, \text { IL-1 } \alpha, \text { IL- } 1 \beta, \text { IL-1RA, } \\
\text { GM-CSF } \downarrow\end{array}$ & NA & NA & NA & NA & $\begin{array}{l}\text { MoRIKAWA et al. } \\
\text { [141] }\end{array}$ \\
\hline & FOM & $\begin{array}{l}\text { Human } \\
\text { (ex vivo) }\end{array}$ & PMN & S. aureus & Phagocytosis and killing $\uparrow$ & NA & NA & NA & NA & $\begin{array}{l}\text { Pérez Fernández } \\
\text { et al. [136] }\end{array}$ \\
\hline
\end{tabular}

$\uparrow$ : Significant increase; $\downarrow$ : significant decrease; $\Leftrightarrow$ : no significant difference; A.: Acinetobacter; AP: activator protein; AZM: azithromycin; BALF: bronchoalveolar lavage fluid; BEC: bronchial epithelial cell; BMDM: bone marrow derived macrophages; C.: Candida; CAM: clarithromycin; CCL: CC chemokine receptor; CMT-3: chemically modified tetracycline-3; COL1A1: $\alpha-1$ type I collagen; CPFX: ciprofloxacin; CSY0073: non-antibiotic derivative of AZM; CXCL: C-X-C motif chemokine ligand; DOX: doxycycline; EM703: non-antibiotic derivative of erythromycin; ERK: extracellular signal-regulated kinase; ERM: erythromycin; FOM: Fosfomycin; G-CSF: granulocyte colony-stimulating factor; GM-CSF: granulocyte-macrophage colony-stimulating factor; H.: Haemophilus; i.b.: intrabronchially; IFN: interferon; i.n. intranasally; iNOS: inducible NO synthase; i.p. intraperitoneally; it. intratracheal; iv.; intravenously; IL: interleukin; JM: josamycin; JNK: c-Jun N-terminal kinase; KC: keratinocytes-derived chemokine; LVFX: levofloxacin; LPS: lipopolysaccharide; LZD: linezolid; M.: Mycoplasma; MAPK: mitogen-activated protein kinase; MCP: monocyte chemoattractant protein; MDA: malondialdehyde; MDSC: myeloid-derived suppressor cell; MIP: macrophage inflammatory protein; MLE: murine lung epithelial; MMP: matrix metalloproteinase; MODS: multi organ dysfunction syndrome; MOX: moxifloxacin; MPO: myeloperoxidase; MRSA: methicillin-resistant Staphylococcus aureus; MSSA: methicillin-sensitive S. aureus; NA: not applicable; ND: not determined; NE: neutrophil elastase; NO: nitric oxide; NLRP3: nucleotide-binding oligomerisation domain-like receptor family, pyrin domain containing protein-3; P.: Pseudomonas; PAF: platelet-activating factor; PBEC: primary bronchial epithelial cell; PBMC: peripheral blood mononuclear cell; PMN: polymorphonuclear neutrophils; RA: receptor antagonist; RCT: randomised controlled trial; RSV: respiratory syncytial virus; ROS: reactive oxygen species; RXM: roxithromycin; S.: Streptococcus; STAT1: signal transducer and activator of transcription 1; SMA: superior mesenteric artery; STNFR: soluble TNF receptor; TBARS: thiobarbituric acid reactive substances; TBLN: tracheobronchial lymph nodes; TEL: telithromycin; TET: tetracycline; TGF- $\beta 1$ : transforming growth factor- $\beta 1$; t.t.: transtracheal; TLR: Toll-like receptor; TNF- $\alpha$ : tumour necrosis factor- $\alpha$; TREM: triggering receptor expressed on myeloid cells; VAP:ventilator-associated pneumonia; VEGF: vascular endothelial growth factor; VRE: vancomycin-resistant enterococci. 
profile in a murine LPS-induced lung injury model [144]. Consistent with the immunomodulatory properties observed for tetracycline, CMT-3 inhibits caspase-1 activation in response to NLRP3 stimulation, thereby inhibiting inflammasome-dependent cytokine release in alveolar leucocytes obtained from ARDS patients [9].

Furthermore, antibiotics should be optimised to make them as safe as possible. Fluoroquinolones for example exhibit certain rare but severe side effects like QT prolongation that are attributed to their chemical structure. Substituting responsible moieties around the core could minimise side effects [119]. Beneficial immunomodulatory effects of antibiotics, e.g. macrolides, can be further augmented by attaching specific molecules such as peptide DP7 [145].

Although antibiotics, especially macrolides and tetracyclines (figure 2), are promising immunomodulatory candidates for ARDS treatment, there is a lack of clinical studies demonstrating a benefit. Since ARDS is a heterogeneous syndrome with significant variability in pathophysiology, severity and outcome [146], this heterogeneity has likely contributed to the lack of clinical studies showing an effect of immunomodulatory antibiotics (and other drugs). Therefore, identifying biological subphenotypes of ARDS patients with activation of identical inflammatory cascades might help to develop enrichment strategies to enable precision medicine for clinical trials. A recent study showed that the inflammasome-caspase- 1 pathway is active in ARDS caused by direct lung injury [9]. Thus, inhibition of caspase- 1 by tetracycline might be more beneficial in patients with direct ARDS rather than indirect lung injury. A randomised clinical trial currently investigates whether doxycycline is effective in direct ARDS in patients with COVID-19 (NCT04371952).

\section{Conclusion}

Distinct antibiotics are potent immunomodulators of the innate immune response inducing a broad range of pro-inflammatory and anti-inflammatory effects that could potentially ameliorate the immune dysregulation present in ARDS. Their immunomodulatory effects are dependent on timing, frequency, dosage and the degree of lung injury. In addition, some of the immunomodulatory effects discovered in preclinical studies seem to contradict clinical observations. The immunomodulatory effects also appear to vary between virusand bacterial-induced lung injury and within antibiotic classes (table 1).

Recent preclinical studies provide a plethora of potent immunomodulatory antibiotics that can be used to limit deleterious inflammation in ARDS. However, they need yet to be further tested in clinical trials and attention should be paid in particular to safety and the development of antibiotic resistance. Identifying immunological and clinical phenotypes of ARDS that will respond to the treatment with immunomodulatory preferably non-antibiotic derivatives is essential and should be considered for future clinical trials.

Provenance: Submitted article, peer reviewed.

Conflict of interest: None declared.

\section{References}

$1 \quad$ Ashbaugh D, Boyd Bigelow D, Petty T, et al. Acute respiratory distress in adults. Lancet 1967; 290: 319-323.

2 Matthay MA, Zemans RL, Zimmerman GA, et al.. Acute respiratory distress syndrome. Nat Rev Dis Primers 2019; 5: 18.

3 Bellani G, Laffey JG, Pham T, et al. The LUNG SAFE study: a presentation of the prevalence of ARDS according to the Berlin Definition! Crit Care 2016; 20: 268.

4 Herridge MS, Tansey CM, Matté A, et al. Functional disability 5 years after acute respiratory distress syndrome. N Engl J Med 2011; 364: 1293-1304.

5 Thompson BT, Chambers RC, Liu KD. Acute respiratory distress syndrome. N Engl J Med 2017; 377: 562-572.

6 Tauber SC, Nau R. Immunomodulatory properties of antibiotics. Curr Mol Pharmacol 2008; 1: 68-79.

7 Welte T. Azithromycin: the holy grail to prevent exacerbations in chronic respiratory disease? Am J Respir Crit Care Med 2019; 200: 269-270.

8 Spyridaki A, Raftogiannis M, Antonopoulou A, et al. Effect of clarithromycin in inflammatory markers of patients with ventilator-associated pneumonia and sepsis caused by Gram-negative bacteria: results from a randomized clinical study. Antimicrob Agents Chemother 2012; 56: 3819-3825.

9 Peukert K, Fox M, Schulz S, et al. Inhibition of caspase-1 with tetracycline ameliorates acute lung injury. $A m$ J Respir Crit Care Med 2021; 204: 53-63.

10 Englert JA, Bobba C, Baron RM. Integrating molecular pathogenesis and clinical translation in sepsis-induced acute respiratory distress syndrome. JCI Insight 2019; 4: e124061. 
Opitz B, van Laak V, Eitel J, et al. Innate immune recognition in infectious and noninfectious diseases of the lung. Am J Respir Crit Care Med 2010; 181: 1294-1309.

Dolinay T, Kim YS, Howrylak J, et al. Inflammasome-regulated cytokines are critical mediators of acute lung injury. Am J Respir Crit Care Med 2012; 185: 1225-1234.

Chen GY, Nuñez G. Sterile inflammation: sensing and reacting to damage. Nat Rev Immunol 2010; 10: 826-837.

Zhang W, Liu HT. MAPK signal pathways in the regulation of cell proliferation in mammalian cells. Cell Res 2002; 12: 9-18.

Guo H, Callaway JB, Ting JP-Y. Inflammasomes: mechanism of action, role in disease, and therapeutics. Nat Med 2015; 21: 677-687.

Hornung V, Latz E. Critical functions of priming and lysosomal damage for NLRP3 activation. Eur J Immunol 2010; 40: 620-623.

Makabe H, Kojika M, Takahashi G, et al. Interleukin-18 levels reflect the long-term prognosis of acute lung injury and acute respiratory distress syndrome. J Anesth 2012; 26: 658-663.

Aggarwal NR, King LS, D’Alessio FR. Diverse macrophage populations mediate acute lung inflammation and resolution. Am J Physiol Lung Cell Mol Physiol 2014; 306: L709-L725.

Hirayama $\mathrm{D}$, lida $\mathrm{T}$, Nakase $\mathrm{H}$. The phagocytic function of macrophage-enforcing innate immunity and tissue homeostasis. Int J Mol Sci 2017; 19: 92.

Xue J, Schmidt SV, Sander J, et al. Transcriptome-based network analysis reveals a spectrum model of human macrophage activation. Immunity 2014; 40: 274-288.

Zemans RL, Matthay MA. What drives neutrophils to the alveoli in ARDS? Thorax 2017; 72: 1-3.

Matthay MA, Zemans RL. The acute respiratory distress syndrome: pathogenesis and treatment. Annu Rev Pathol 2011; 6: 147-163.

Poon IKH, Lucas CD, Rossi AG, et al. Apoptotic cell clearance: basic biology and therapeutic potential. Nat Rev Immunol 2014; 14: 166-180.

Matute-Bello G, Liles WC, Radella F, et al. Modulation of neutrophil apoptosis by granulocyte colony-stimulating factor and granulocyte/macrophage colony-stimulating factor during the course of acute respiratory distress syndrome. Crit Care Med 2000; 28: 1-7.

Juss JK, House D, Amour A, et al. Acute respiratory distress syndrome neutrophils have a distinct phenotype and are resistant to phosphoinositide 3-kinase inhibition. Am J Respir Crit Care Med 2016; 194: 961-973.

Fialkow L, Fochesatto Filho L, Bozzetti MC, et al. Neutrophil apoptosis: a marker of disease severity in sepsis and sepsis-induced acute respiratory distress syndrome. Crit Care 2006; 10: R155.

Zuckerman JM. Macrolides and ketolides: azithromycin, clarithromycin, telithromycin. Infect Dis Clin North Am 2004; 18: 621-649.

Zimmermann P, Ziesenitz VC, Curtis N, et al. The immunomodulatory effects of macrolides-a systematic review of the underlying mechanisms. Front Immunol 2018; 9: 302.

Gualdoni GA, Lingscheid T, Schmetterer KG, et al. Azithromycin inhibits IL-1 secretion and non-canonical inflammasome activation. Sci Rep 2015; 5: 12016.

Fan L-C, Lin J-L, Yang J-W, et al. Macrolides protect against Pseudomonas aeruginosa infection via inhibition of inflammasomes. Am J Physiol Lung Cell Mol Physiol 2017; 313: L677-L686.

Bosnar M, Čužić S, Bošnjak B, et al. Azithromycin inhibits macrophage interleukin-1 $\beta$ production through inhibition of activator protein-1 in lipopolysaccharide-induced murine pulmonary neutrophilia. Int Immunopharmacol 2011; 11: 424-434.

Desaki M, Okazaki H, Sunazuka T, et al. Molecular mechanisms of anti-inflammatory action of erythromycin in human bronchial epithelial cells: possible role in the signaling pathway that regulates nuclear factor-kappaB activation. Antimicrob Agents Chemother 2004; 48: 1581-1585.

Haydar D, Cory TJ, Birket SE, et al. Azithromycin polarizes macrophages to an M2 phenotype via inhibition of the STAT1 and NF-KB signaling pathways. J Immunol 2019; 203: 1021-1030.

Yamaya M, Shinya K, Hatachi $\mathrm{Y}$, et al. Clarithromycin inhibits type a seasonal influenza virus infection in human airway epithelial cells. J Pharmacol Exp Ther 2010; 333: 81-90.

Stellari FF, Sala A, Donofrio G, et al. Azithromycin inhibits nuclear factor-kB activation during lung inflammation: an in vivo imaging study. Pharmacol Res Perspect 2014; 2: e00058.

Amado-Rodríguez L, González-López A, López-Alonso I, et al. Anti-inflammatory effects of clarithromycin in ventilator-induced lung injury. Respir Res 2013; 14: 52.

Bode C, Diedrich B, Muenster S, et al. Antibiotics regulate the immune response in both presence and absence of lipopolysaccharide through modulation of Toll-like receptors, cytokine production and phagocytosis in vitro. Int Immunopharmacol 2014; 18: 27-34.

Feola DJ, Garvy BA, Cory TJ, et al. Azithromycin alters macrophage phenotype and pulmonary compartmentalization during lung infection with Pseudomonas. Antimicrob Agents Chemother 2010; 54: 2437-2447.

Namkoong $\mathrm{H}$, Ishii M, Fujii $\mathrm{H}$, et al. Clarithromycin expands CD11b+Gr-1+ cells via the STAT3/Bv8 axis to ameliorate lethal endotoxic shock and post-influenza bacterial pneumonia. PLoS Pathog 2018; 14: e1006955. 
Tang F, Li R, Xue J, et al. Azithromycin attenuates acute radiation-induced lung injury in mice. Oncol Lett 2017; 14: 5211-5220

Mosquera RA, De Jesus-Rojas W, Stark JM, et al. Role of prophylactic azithromycin to reduce airway inflammation and mortality in a RSV mouse infection model. Pediatr Pulmonol 2018; 53: 567-574.

Lee N, Wong C-K, Chan MCW, et al. Anti-inflammatory effects of adjunctive macrolide treatment in adults hospitalized with influenza: a randomized controlled trial. Antiviral Res 2017; 144: 48-56.

Bosnar M, Bosnjak B, Cuzic S, et al. Azithromycin and clarithromycin inhibit lipopolysaccharide-induced murine pulmonary neutrophilia mainly through effects on macrophage-derived granulocyte-macrophage colony-stimulating factor and interleukin-1beta. J Pharmacol Exp Ther 2009; 331: 104-113.

Kumar V, Harjai K, Chhibber S. Effect of clarithromycin on lung inflammation and alveolar macrophage function in Klebsiella penumoniae B5055-induced acute lung infection in BALB/c mice. J Chemother 2008; 20: 609-614.

Kawashima M, Yatsunami J, Fukuno Y, et al. Inhibitory effects of 14-membered ring macrolide antibiotics on bleomycin-induced acute lung injury. Lung 2002; 180: 73-89.

Tsai WC, Rodriguez ML, Young KS, et al. Azithromycin blocks neutrophil recruitment in Pseudomonas endobronchial infection. Am J Respir Crit Care Med 2004; 170: 1331-1339.

Nakamura S, Yanagihara K, Araki N, et al. Efficacy of clarithromycin against experimentally induced pneumonia caused by clarithromycin-resistant Haemophilus influenzae in mice. Antimicrob Agents Chemother 2010; 54: 757-762.

Yamada K, Yanagihara K, Kaku N, et al. Azithromycin attenuates lung inflammation in a mouse model of ventilator-associated pneumonia by multidrug-resistant Acinetobacter baumannii. Antimicrob Agents Chemother 2013; 57: 3883-3888.

Murphy DM, Forrest IA, Corris PA, et al. Azithromycin attenuates effects of lipopolysaccharide on lung allograft bronchial epithelial cells. J Heart Lung Transplant 2008; 27: 1210-1216.

Hardy RD, Rios AM, Chavez-Bueno S, et al. Antimicrobial and immunologic activities of clarithromycin in a murine model of Mycoplasma pneumoniae-induced pneumonia. Antimicrob Agents Chemother 2003; 47: 1614-1620.

Yokota S, Okabayashi T, Hirakawa S, et al. Clarithromycin suppresses human respiratory syncytial virus infection-induced Streptococcus pneumoniae adhesion and cytokine production in a pulmonary epithelial cell line. Mediators Inflamm 2012; 2012: 528568.

Grégoire M, Uhel F, Lesouhaitier M, et al. Impaired efferocytosis and neutrophil extracellular trap clearance by macrophages in ARDS. Eur Respir J 2018; 52: 1702590.

Hodge S, Hodge G, Brozyna S, et al. Azithromycin increases phagocytosis of apoptotic bronchial epithelial cells by alveolar macrophages. Eur Respir J 2006; 28: 486-495.

Gao X, Ray R, Xiao Y, et al. Macrolide antibiotics improve chemotactic and phagocytic capacity as well as reduce inflammation in sulfur mustard-exposed monocytes. Pulm Pharmacol Ther 2010; 23: 97-106.

Hodge S, Reynolds PN. Low-dose azithromycin improves phagocytosis of bacteria by both alveolar and monocyte-derived macrophages in chronic obstructive pulmonary disease subjects. Respirology 2012; 17: 802-807.

Murphy BS, Sundareshan V, Cory TJ, et al. Azithromycin alters macrophage phenotype. J Antimicrob Chemother 2008; 61: 554-560.

Marshall R, Bellingan G, Laurent G. The acute respiratory distress syndrome: fibrosis in the fast lane. Thorax 1998; 53: 815-817.

Burnham EL, Janssen WJ, Riches DWH, et al. The fibroproliferative response in acute respiratory distress syndrome: mechanisms and clinical significance. Eur Respir J 2014; 43: 276-285.

Wuyts WA, Willems S, Vos R, et al. Azithromycin reduces pulmonary fibrosis in a bleomycin mouse model. Exp Lung Res 2010; 36: 602-614.

Gladue RP, Snider ME. Intracellular accumulation of azithromycin by cultured human fibroblasts. Antimicrob Agents Chemother 1990; 34: 1056-1060.

Ikeda $\mathrm{H}$, Sunazuka T, Suzuki H, et al. EM703, the new derivative of erythromycin, inhibits transcription of type I collagen in normal and scleroderma fibroblasts. J Dermatol Sci 2008; 49: 195-205.

inhibition of TGF-beta signaling in lung fibroblasts. Respir Res 2006; 7: 16.

Sato K, Suga M, Akaike T, et al. Therapeutic effect of erythromycin on influenza virus-induced lung injury in mice. Am J Respir Crit Care Med 1998; 157: 853-857.

Fage C, Pizzorno A, Rhéaume C, et al. The combination of oseltamivir with azithromycin does not show additional benefits over oseltamivir monotherapy in mice infected with influenza $A(H 1 N 1) p d m 2009$ virus. J Med Virol 2017; 89: 2239-2243.

65 Simonis FD, de ludicibus G, Cremer OL, et al. Macrolide therapy is associated with reduced mortality in acute respiratory distress syndrome (ARDS) patients. Ann Transl Med 2018; 6: 24. 
Walkey AJ, Wiener RS. Macrolide antibiotics and survival in patients with acute lung injury. Chest 2012; 141 1153-1159.

Kawamura K, Ichikado K, Takaki M, et al. Efficacy of azithromycin in sepsis-associated acute respiratory distress syndrome: a retrospective study and propensity score analysis. Springerplus 2016; 5: 1193.

Hung IFN, To KKW, Chan JFW, et al. Efficacy of clarithromycin-naproxen-oseltamivir combination in the treatment of patients hospitalized for influenza A(H3N2) infection: an open-label randomized, controlled, phase IIb/III trial. Chest 2017; 151: 1069-1080.

Kawamura K, Ichikado K, Takaki M, et al. Adjunctive therapy with azithromycin for moderate and severe acute respiratory distress syndrome: a retrospective, propensity score-matching analysis of prospectively collected data at a single center. Int J Antimicrob Agents 2018; 51: 918-924.

Lorenzo M-J, Moret I, Sarria B, et al. Lung inflammatory pattern and antibiotic treatment in pneumonia. Respir Res 2015; 16: 15.

Kong M, Zhang WW, Sewell K, et al. Azithromycin treatment vs placebo in children with respiratory syncytial virus-induced respiratory failure. JAMA Netw Open 2020; 3: e203482.

Pons S, Timsit J-F, Ruckly S, et al. Impact of macrolide therapy in critically ill patients with acute respiratory failure: a desirability of outcome ranking analysis to investigate the OUTCOMEREA database. Intensive Care Med 2019; 45: 1043-1045.

Lotter K, Höcherl K, Bucher M, et al. In vivo efficacy of telithromycin on cytokine and nitric oxide formation in lipopolysaccharide-induced acute systemic inflammation in mice. J Antimicrob Chemother 2006; 58: 615-621.

Araujo FG, Slifer TL, Remington JS. Inhibition of secretion of interleukin-1alpha and tumor necrosis factor alpha by the ketolide antibiotic telithromycin. Antimicrob Agents Chemother 2002; 46: 3327-3330.

Leiva M, Ruiz-Bravo A, Jimenez-Valera M. Effects of telithromycin in in vitro and in vivo models of lipopolysaccharide-induced airway inflammation. Chest 2008; 134: 20-29.

Griffin MO, Fricovsky E, Ceballos G, et al. Tetracyclines: a pleitropic family of compounds with promising therapeutic properties. Review of the literature. Am J Physiol Cell Physiol 2010; 299: C539-C548.

Golub LM, Lee HM, Ryan ME, et al. Tetracyclines inhibit connective tissue breakdown by multiple non-antimicrobial mechanisms. Adv Dent Res 1998; 12: 12-26.

Steinberg J, Halter J, Schiller HJ, et al. Metalloproteinase inhibition reduces lung injury and improves survival after cecal ligation and puncture in rats. J Surg Res 2003; 111: 185-195.

Moon A, Gil S, Gill SE, et al. Doxycycline impairs neutrophil migration to the airspaces of the lung in mice exposed to intratracheal lipopolysaccharide. J Inflamm 2012; 9: 31.

Sochor M, Richter S, Schmidt A, et al. Inhibition of matrix metalloproteinase-9 with doxycycline reduces pancreatitis-associated lung injury. Digestion 2009; 80: 65-73.

Fujita M, Harada E, Ikegame S, et al. Doxycycline attenuated lung injury by its biological effect apart from its antimicrobial function. Pulm Pharmacol Ther 2007; 20: 669-675.

Zhang C, Gong W, Liu H, et al. Inhibition of matrix metalloproteinase-9 with low-dose doxycycline reduces acute lung injury induced by cardiopulmonary bypass. Int J Clin Exp Med 2014; 7: 4975-4982.

Carney DE, Lutz CJ, Picone AL, et al. Matrix metalloproteinase inhibitor prevents acute lung injury after cardiopulmonary bypass. Circulation 1999; 100: 400-406.

Patel $\mathrm{A}$, Khande $\mathrm{H}$, Periasamy $\mathrm{H}$, et al. Immunomodulatory effect of doxycycline ameliorates systemic and pulmonary inflammation in a murine polymicrobial sepsis model. Inflammation 2020; 43: 1035-1043.

Wang C-T, Zhang L, Wu H-W, et al. Doxycycline attenuates acute lung injury following cardiopulmonary bypass: involvement of matrix metalloproteinases. Int J Clin Exp Pathol 2014; 7: 7460-7468.

Roy SK, Kubiak BD, Albert SP, et al. Chemically modified tetracycline 3 prevents acute respiratory distress syndrome in a porcine model of sepsis+ischemia/reperfusion-induced lung injury. Shock 2012; 37: 424-432.

Steinberg J, Halter J, Schiller H, et al. Chemically modified tetracycline prevents the development of septic shock and acute respiratory distress syndrome in a clinically applicable porcine model. Shock 2005; 24: 348-356.

Kim JH, Suk MH, Yoon DW, et al. Inhibition of matrix metalloproteinase-9 prevents neutrophilic inflammation in ventilator-induced lung injury. Am J Physiol Lung Cell Mol Physiol 2006; 291: L580-L587.

Sapru A, Calfee CS, Liu KD, et al. Plasma soluble thrombomodulin levels are associated with mortality in the acute respiratory distress syndrome. Intensive Care Med 2015; 41: 470-478.

Patel BV, Wilson MR, O'Dea KP, et al. TNF-induced death signaling triggers alveolar epithelial dysfunction in acute lung injury. J Immunol 2013; 190: 4274-4282.

$\mathrm{Ng} \mathrm{HH}$, Narasaraju T, Phoon MC, et al. Doxycycline treatment attenuates acute lung injury in mice infected with virulent influenza H3N2 virus: involvement of matrix metalloproteinases. Exp Mol Pathol 2012; 92: 287-295.

McCann UG, Gatto LA, Searles B, et al. Matrix metalloproteinase inhibitor: differential effects on pulmonary neutrophil and monocyte sequestration following cardiopulmonary bypass. J Extra Corpor Technol 1999; 31: 67-75.

Carney DE, McCann UG, Schiller HJ, et al. Metalloproteinase inhibition prevents acute respiratory distress syndrome. J Surg Res 2001; 99: 245-252. 
Zhou X, Wang D, Ballard-Croft CK, et al. A tetracycline analog improves acute respiratory distress syndrome survival in an ovine model. Ann Thorac Surg 2010; 90: 419-426.

Ager S, Gould K. Clinical update on linezolid in the treatment of Gram-positive bacterial infections. Infect Drug Resist 2012; 5: 87-102.

Akinnusi ME, Hattemer A, Gao W, et al. Does linezolid modulate lung innate immunity in a murine model of methicillin-resistant Staphylococcus aureus pneumonia? Crit Care Med 2011; 39: 1944-1952.

Jacqueline C, Broquet A, Roquilly $A$, et al. Linezolid dampens neutrophil-mediated inflammation in methicillin-resistant Staphylococcus aureus-induced pneumonia and protects the lung of associated damages. J Infect Dis 2014; 210: 814-823.

Luna CM, Bruno DA, García-Morato J, et al. Effect of linezolid compared with glycopeptides in methicillin-resistant Staphylococcus aureus severe pneumonia in piglets. Chest 2009; 135: 1564-1571.

Chen J, Feng G, Song Y, et al. Linezolid exerts greater bacterial clearance but no modification of host lung gene expression profiling: a mouse MRSA pneumonia model. PLOS ONE 2013; 8: e67994.

Pauchard LA, Blot M, Bruyere R, et al. Linezolid and atorvastatin impact on pneumonia caused by Staphyloccocus aureus in rabbits with or without mechanical ventilation. PLOS ONE 2017; 12: e0187187.

Yoshizawa S, Tateda K, Saga T, et al. Virulence-suppressing effects of linezolid on methicillin-resistant Staphylococcus aureus: possible contribution to early defervescence. Antimicrob Agents Chemother 2012; 56: 1744-1748.

Morris DE, Cleary DW, Clarke SC. Secondary bacterial infections associated with influenza pandemics. Front Microbiol 2017; 8: 1041.

Breslow-Deckman J, Mattingly C, Birket S, et al. Linezolid decreases susceptibility to secondary bacterial pneumonia postinfluenza infection in mice through its effects on IFN- $\gamma$. J Immunol 2013; 191: 1792-1799.

McNamee LA, Harmsen AG. Both influenza-induced neutrophil dysfunction and neutrophil-independent mechanisms contribute to increased susceptibility to a secondary Streptococcus pneumoniae infection. Infect Immun 2006; 74: 6707-6721.

van der Sluijs KF, Nijhuis M, Levels JHM, et al. Influenza-induced expression of indoleamine 2,3-dioxygenase enhances interleukin-10 production and bacterial outgrowth during secondary pneumococcal pneumonia. $J$ Infect Dis 2006; 193: 214-222.

van der Sluijs KF, van Elden LJR, Nijhuis M, et al. IL-10 is an important mediator of the enhanced susceptibility to pneumococcal pneumonia after influenza infection. J Immunol 2004; 172: 7603-7609.

Sun K, Metzger DW. Inhibition of pulmonary antibacterial defense by interferon-gamma during recovery from influenza infection. Nat Med 2008; 14: 558-564.

Bansal S, Yajjala VK, Bauer C, et al. Influenza-induced interferon- $\gamma$ promotes alveolar macrophage depletion during secondary pneumococcal infection. J Immunol 2018; 200: 1 Suppl., 108.5.

Liu X, He Y, Xiao K, et al. Effect of linezolid on clinical severity and pulmonary cytokines in a murine model of influenza A and Staphylococcus aureus coinfection. PLOS ONE 2013; 8: e57483.

Bhan U, Podsiad AB, Kovach MA, et al. Linezolid has unique immunomodulatory effects in post-influenza community acquired MRSA pneumonia. PLOS ONE 2015; 10: e0114574.

Verma AK, Bauer C, Yajjala VK, et al. Linezolid attenuates lethal lung damage during postinfluenza methicillin-resistant Staphylococcus aureus pneumonia. Infect Immun 2019; 87: e00538-19.

Garcia-Roca P, Mancilla-Ramirez J, Santos-Segura A, et al. Linezolid diminishes inflammatory cytokine production from human peripheral blood mononuclear cells. Arch Med Res 2006; 37: 31-35.

3 Franks Z, Campbell RA, Vieira de Abreu A, et al. Methicillin-resistant Staphylococcus aureus-induced thrombo-inflammatory response is reduced with timely antibiotic administration. Thromb Haemost 2013; 109: 684-695.

114 Bode C, Muenster S, Diedrich B, et al. Linezolid, vancomycin and daptomycin modulate cytokine production, Toll-like receptors and phagocytosis in a human in vitro model of sepsis. J Antibiot (Tokyo) 2015; 68: 485-490.

5 Grüger T, Schmidt T, Schnitzler N, et al. Negative impact of linezolid on human neutrophil functions in vitro. Chemotherapy 2012; 58: 206-211.

Ballesta S, Pascual A, García I, et al. Effect of linezolid on the phagocytic functions of human polymorphonuclear leukocytes. Chemotherapy 2003; 49: 163-166.

Naess A, Stenhaug Kilhus K, Nystad TW, et al. Linezolid and human polymorphonuclear leukocyte function. Chemotherapy 2006; 52: 122-124.

Evans SJ, Roberts AEL, Morris AC, et al. Contrasting effects of linezolid on healthy and dysfunctional human neutrophils: reducing C5a-induced injury. Sci Rep 2020; 10: 16377.

Mandell L, Tillotson G. Safety of fluoroquinolones: an update. Can J Infect Dis 2002; 13: 54-61.

Frei CR, Labreche MJ, Attridge RT. Fluoroquinolones in community-acquired pneumonia. Drugs 2011; 71: 757-770. Akamatsu $\mathrm{H}$, Niwa $\mathrm{Y}$, Sasaki $\mathrm{H}$, et al. Effect of pyridone carboxylic acid anti-microbials on the generation of reactive oxygen species in vitro. $J$ Int Med Res 1996; 24: 345-351. 
122 Enoki $\mathrm{Y}$, Ishima $\mathrm{Y}$, Tanaka R, et al. Pleiotropic effects of levofloxacin, fluoroquinolone antibiotics, against influenza virus-induced lung injury. PLOS ONE 2015; 10: e0130248.

123 Beisswenger C, Honecker A, Kamyschnikow A, et al. Moxifloxacin modulates inflammation during murine pneumonia. Respir Res 2014; 15: 82.

124 Huang H-C, Shieh C-C, Yu W-L, et al. Comparing the protective effects of ciprofloxacin, moxifloxacin and levofloxacin in mice with lipopolysaccharide-induced acute lung injuries. Respirology 2008; 13: 47-52.

125 Shalit I, Horev-Azaria L, Fabian I, et al. Immunomodulatory and protective effects of moxifloxacin against Candida albicans-induced bronchopneumonia in mice injected with cyclophosphamide. Antimicrob Agents Chemother 2002; 46: 2442-2449.

126 Müller-Redetzky HC, Wienhold SM, Berg J, et al. Moxifloxacin is not anti-inflammatory in experimental pneumococcal pneumonia. J Antimicrob Chemother 2015; 70: 830-840.

127 Dalhoff A. Immunomodulatory activities of fluoroquinolones. Infection 2005; 33: 55-70.

128 Rabehi L, Irinopoulou T, Cholley B, et al. Gram-positive and Gram-negative bacteria do not trigger monocytic cytokine production through similar intracellular pathways. Infect Immun 2001; 69: 4590-4599.

129 Vlahos R, Stambas J, Selemidis S. Suppressing production of reactive oxygen species (ROS) for influenza A virus therapy. Trends Pharmacol Sci 2012; 33: 3-8.

130 Imai Y, Kuba K, Neely GG, et al. Identification of oxidative stress and Toll-like receptor 4 signaling as a key pathway of acute lung injury. Cell 2008; 133: 235-249.

131 Akaike T, Noguchi Y, ljiri S, et al. Pathogenesis of influenza virus-induced pneumonia: involvement of both nitric oxide and oxygen radicals. Proc Natl Acad Sci USA 1996; 93: 2448-2453.

132 Filler SG, Yeaman MR, Sheppard DC. Tumor necrosis factor inhibition and invasive fungal infections. Clin Infect Dis 2005; 41: Suppl. 3, S208-S212.

133 Marino MW, Dunn A, Grail D, et al. Characterization of tumor necrosis factor-deficient mice. Proc Natl Acad Sci USA 1997; 94: 8093-8098.

134 Trinh TD, Smith JR, Rybak MJ. Parenteral fosfomycin for the treatment of multidrug resistant bacterial infections: the rise of the epoxide. Pharmacotherapy 2019; 39: 1077-1094.

135 Shen F, Tang X, Cheng W, et al. Fosfomycin enhances phagocyte-mediated killing of Staphylococcus aureus by extracellular traps and reactive oxygen species. Sci Rep 2016; 6: 19262.

136 Pérez Fernández P, Herrera I, Martínez P, et al. Enhancement of the susceptibility of Staphylococcus aureus to phagocytosis after treatment with fosfomycin compared with other antimicrobial agents. Chemotherapy 1995; 41: 45-49.

137 Yildiz IE, Topcu A, Bahceci I, et al. The protective role of fosfomycin in lung injury due to oxidative stress and inflammation caused by sepsis. Life Sci 2021; 279: 119662.

138 An Y, Wang Y, Zhan J, et al. Fosfomycin protects mice from Staphylococcus aureus pneumonia caused by $\alpha$-hemolysin in extracellular vesicles by inhibiting MAPK-regulated NLRP3 inflammasomes. Front Cell Infect Microbiol 2019; 9: 253.

139 Matsumoto T, Tateda K, Miyazaki S, et al. Fosfomycin alters lipopolysaccharide-induced inflammatory cytokine production in mice. Antimicrob Agents Chemother 1999; 43: 697-698.

140 Zeitlinger M, Marsik C, Steiner I, et al. Immunomodulatory effects of fosfomycin in an endotoxin model in human blood. J Antimicrob Chemother 2007; 59: 219-223.

141 Morikawa K, Watabe $\mathrm{H}$, Araake M, et al. Modulatory effect of antibiotics on cytokine production by human monocytes in vitro. Antimicrob Agents Chemother 1996; 40: 1366-1370.

142 Sauermann R, Marsik C, Steiner I, et al. Immunomodulatory effects of fosfomycin in experimental human endotoxemia. Antimicrob Agents Chemother 2007; 51: 1879-1881.

143 Sadamatsu H, Takahashi K, Tashiro H, et al. The non-antibiotic macrolide EM900 attenuates HDM and poly(l: C)-induced airway inflammation with inhibition of macrophages in a mouse model. Inflamm Res 2020; 69: 139-151.

144 Balloy V, Deveaux A, Lebeaux D, et al. Azithromycin analogue CSY0073 attenuates lung inflammation induced by LPS challenge. Br J Pharmacol 2014; 171: 1783-1794.

145 Liu X, Li Z, Wang X, et al. Novel antimicrobial peptide-modified azithromycin-loaded liposomes against methicillin-resistant Staphylococcus aureus. Int J Nanomedicine 2016; 11: 6781-6794.

146 Peukert K, Seeliger B, Fox M, et al. SP-D serum levels reveal distinct epithelial damage in direct human ARDS. J Clin Med 2021; 10: 737.

147 Zhang $\mathrm{F}$, Hu L, Wu Y-X, et al. Doxycycline alleviates paraquat-induced acute lung injury by inhibiting neutrophil-derived matrix metalloproteinase 9. Int Immunopharmacol 2019; 72: 243-251.

148 Yanagihara K, Kihara R, Araki N, et al. Efficacy of linezolid against Panton-Valentine leukocidin (PVL)-positive meticillin-resistant Staphylococcus aureus (MRSA) in a mouse model of haematogenous pulmonary infection. Int J Antimicrob Agents 2009; 34: 477-481.

149 Ubagai T, Sato Y, Kamoshida G, et al. Immunomodulatory gene expression analysis in LPS-stimulated human polymorphonuclear leukocytes treated with antibiotics commonly used for multidrug-resistant strains. Mol Immunol 2021; 129: 39-44. 